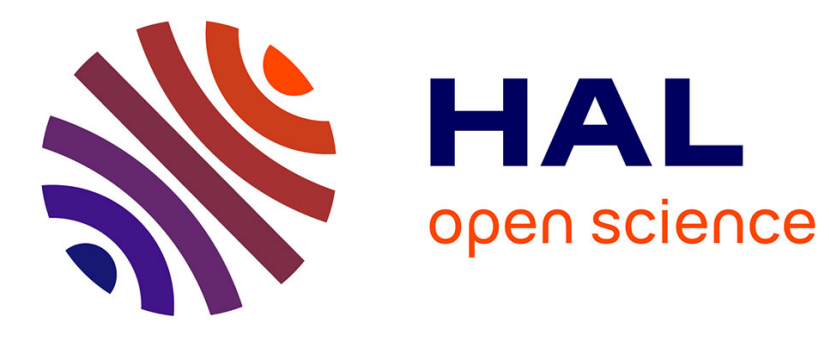

\title{
Variability of N Export in Water: A Review
}

Jean Causse, Estelle Baurès, Yoann Méry, Aude-Valérie Jung, Olivier Thomas

\section{To cite this version:}

Jean Causse, Estelle Baurès, Yoann Méry, Aude-Valérie Jung, Olivier Thomas. Variability of N Export in Water: A Review. Critical Reviews in Environmental Science and Technology, 2015, 45 (20), pp.2245-2281. 10.1080/10643389.2015.1010432 . hal-01195736

\section{HAL Id: hal-01195736 \\ https://hal-univ-rennes1.archives-ouvertes.fr/hal-01195736}

Submitted on 2 Nov 2020

HAL is a multi-disciplinary open access archive for the deposit and dissemination of scientific research documents, whether they are published or not. The documents may come from teaching and research institutions in France or abroad, or from public or private research centers.
L'archive ouverte pluridisciplinaire HAL, est destinée au dépôt et à la diffusion de documents scientifiques de niveau recherche, publiés ou non, émanant des établissements d'enseignement et de recherche français ou étrangers, des laboratoires publics ou privés.

\section{(c)(1)}

Distributed under a Creative Commons Attribution| 4.0 International License 


\title{
Variability of $\mathbf{N}$ Export in Water: A Review
}

\author{
JEAN CAUSSE, ${ }^{1,2,3}$ ESTELLE BAURÈS, ${ }^{1,2}$ YOANN MERY, ${ }^{3}$ \\ AUDE-VALÉRIE JUNG ${ }^{1,2,4}$ and OLIVIER THOMAS ${ }^{1,2}$ \\ ${ }^{1}$ EHESP Rennes, Sorbonne Paris Cité, Rennes Cedex, France \\ ${ }^{2}$ INSERM U 1085-IRSET, LERES, Rennes Cedex, France \\ ${ }^{3}$ Coop de France Ouest, Maison de l'Agriculture, Rennes Cedex, France \\ ${ }^{4}$ School of Environmental Engineering, Campus de Ker-Lann, Bruz, France
}

\begin{abstract}
In spite of several studies on factors affecting nitrogen ( $N$ ) export in water, the spatiotemporal variability of $N$ export is rarely addressed. This review aims at discussing the different factors involved in $N$ export in water and the intra-annual variability of $N$ occurrences in rivers at a watershed scale. From the analysis of the existing works some recommendations on future research work are proposed regarding ( $i$ ) other $N$ forms than nitrate being systematically considered for routine analysis or experimental studies (at least Kjheldal nitrogen), (ii) bydrologists and biogeochemists working together to better understanding of $N$ dynamics according to water pathways, especially during "situations at risk," (iii) water quality monitoring being reinforced both spatially and temporally, especially thanks to bigh frequency instrumentation, and (iv) accurate data on watersheds needed to give better explanations of $N$ variations. We argue that a better understanding of spatiotemporal variability could greatly enhance the remediation of $N$ export impacts, which is crucial to anticipate the impacts of global changes.
\end{abstract}

(c) Jean Causse, Estelle Baurès, Yoann Mery, Aude-Valérie Jung, and Olivier Thomas

This is an Open Access article distributed under the terms of the Commons Attribution License (http://creativecommons.org/licenses/by/3.0), which permits unrestricted use, distribution, and reproduction in any medium, provided the original work is properly cited. The moral rights of the named author(s) have been asserted.

Address correspondence to Estelle Baurès, EHESP Rennes, Sorbonne Paris Cité, Avenue du Professeur Léon Bernard - CS 74312 35043, Rennes Cedex, France. E-mail: Estelle.Baures@ehesp.fr

Color versions of one or more of the figures in the article can be found online at www.tandfonline.com/best. 
KEY WORDS: hydrological processes, nitrogen sources and export, rural watershed, situations at risk, spatiotemporal variability

\section{INTRODUCTION}

Excess of nutrients in water is a recognized threat for ecosystems and human health. Increases of nitrate concentrations in rivers remain one of the most serious environmental concerns, as it affects both developing and developed countries, with a high degree of advancement (Galloway et al., 2008). The main factors are the demographic explosion with development of anthropogenic activities resulting in increases of waste volumes, deforestation for agricultural lands, increases of fertilizer use, intensification of animal production... . Scientists have pointed out the effect of such uncontrolled development on human health since 1945 regarding high concentration of nitrate in drinking water (Comly, 1945; Fewtrell, 2004; Greer and Shannon, 2005) and others pathologies like cancers and reproductive outcomes (Ward et al., 2005) or on the sustainability of ecosystems since the beginning of the 1970s (Ryther and Dunstan, 1971). Concerning factors affecting the export of nitrogen a lot of works have been published during the last decade (Drewry et al., 2006; Pellerin et al., 2006; Schindler et al., 2006; Alvarez-Cobelas et al., 2008; Howarth, 2008; Sutton et al., 2011; Pärn et al., 2012). In spite of many efforts made to reduce nitrate discharge from waste water treatment plants (De Wit and Bendoricchio, 2001; Thieu et al., 2010) diffuse contaminations from agricultural activities and urban infrastructure malfunctions are still unresolved problems. Regarding agricultural issues, many publications aimed at assessing the beneficial effects of changing agricultural practices [best management practices (BMPs)] (Behera and Panda, 2006; Rao et al., 2009; Laurent and Ruelland, 2011), natural buffer areas (Fisher and Acreman, 2004; Anbumozhi et al., 2005; Sahu and Gu, 2009; Borin et al., 2010; Ranalli and Macalady, 2010), and development of constructed agro-ecological infrastructures (constructed wetland, denitrifying barriers) (Blowes et al., 2000; Vymazal, 2007; Mousavi et al., 2012; Schmidt and Clark, 2012; Tanner et al., 2012). Globally, substantial efforts have been made by the agricultural community with respect to a tighter legislation (e.g., European Directive 91/676/CEE, 1991). However, the complexity of natural systems and their interactions with anthropogenic activities are still hindering determination of remediation priorities. If current knowledge is sufficient to carry out mitigation actions, the improvement of scientific knowledge is still needed for a better understanding of nutrient dynamics at various spatiotemporal scales at least to answer the following questions. How does spatiotemporal variability impacts mitigation actions prioritization? What are the effects of heavy rainfalls and/or variations in anthropogenic activities on 
global nitrogen export at the watershed scale during one hydrological year? To what extent are other nitrogen forms than nitrate involved in global $\mathrm{N}$ export during these periods "at risk"? In this context, the aim of this review is to summarize the current knowledge on nitrogen export at short-term (event) and mid-term (season). Long-term studies are also considered in order to show the impacts of land use and climate change on N export. Finally, some actions for future research work are proposed.

\section{N SOURCES}

\subsection{N Forms}

Dissolved nitrogen in water can take several forms, mainly nitrate $\left(\mathrm{NO}_{3}{ }^{-}\right)$ but also nitrite $\left(\mathrm{NO}_{2}{ }^{-}\right)$, ammonium $\left(\mathrm{NH}_{4}{ }^{+}\right)$and organic nitrogen $\left(\mathrm{N}_{\text {org }}\right)$, this last coming from organic matter decomposition and giving ammonium by mineralization. Ammonium can be oxidized into nitrite and then nitrate by nitrification. Nitrate is the main dissolved compound found in freshwater as it is both the most soluble and mobile. It originates from nitrification and fertilizers and can be denitrified to $\mathrm{N}$ gas (denitrification), uptaken by plants, or more rarely transformed into ammonium under reducing conditions (ammonification) (Robertson and Groffman, 2007).

Several studies show contradictory results on $\mathrm{N}$ form proportions between surface runoff and groundwater. On one hand, $\mathrm{NO}_{3}{ }^{-}$is rather transported via groundwater because of its high mobility whereas the other forms are exported via surface runoff with particles (Robertson and Groffman, 2007). On the other hand, ammonium and organic nitrogen can also be transported in groundwater (Kroeger et al., 2006; Jiao et al., 2010) whereas nitrate can be a substantial form of $\mathrm{N}$ loads in surface runoff/lateral flow under high fertilization plots (Jaynes et al., 2001; Zheng et al., 2004; Chen et al., 2012).

At the watershed scale, balance between all forms of nitrogen in river can widely vary depending on land use, $\mathrm{N}$ sources, human activities, hydroclimatic variability, and watershed characteristics. For example, Udawatta et al. (2006) observed in three adjacent agricultural watersheds that the mean nitrate percentage in total nitrogen load in runoff was less than $43 \%$ during soybean years against $63 \%$ for corn years. Another example is provided by Taylor et al. (2005), who found similar proportions of dissolved inorganic and organic nitrogen (50/50) in Melbourne urban catchment, while they found about two-third proportion of organic nitrogen in international literature.

In Europe, nitrogen flows and budgets have been estimated for terrestrial ecosystems (agriculture, forest, and other ecosystems) and for all combined (systems including urban, transport, industrial, and aquatic flows) (Sutton et al., 2011). The distribution of reactive forms (especially nitrate and ammonium) in aquatic systems is dominated by nitrate losses, which are larger in 
areas with high livestock density and precipitation excess, while more localized peaks are associated with urban wastewaters. The budget highlights the central role of crop production and livestock farming. The annual reactive forms brought to agricultural soils represent $27.5 \mathrm{Tg} \mathrm{N}$ (among $11.2 \mathrm{Tg} \mathrm{N}$ as synthetic fertilizers, 7.1 Tg $\mathrm{N}$ as manure, $2.4 \mathrm{Tg} \mathrm{N}$ as atmospheric deposition, 1.0 $\mathrm{Tg} \mathrm{N}$ through biological nitrogen fixation, and 5.8 $\mathrm{Tg} \mathrm{N}$ as crop residues), which are over the requirements for crop production $(17.6 \mathrm{Tg} \mathrm{N})$.

The review of current studies dealing with nitrogen environmental sources and fate, also highlights a tendency to address individual reactive species $\left(\mathrm{NO}_{3}{ }^{-}, \mathrm{NH}_{4}{ }^{+}\right)$from specific sectorial sources (agriculture, traffic, industry), media (air, freshwater, marine), and for specific issues in general (climate, urban air pollution, biodiversity, water quality, etc.).

\subsection{Type of Sources}

Two types of river contamination sources are usually distinguished, according to production modes: point source (PS) and non-point source (NPS). Beside this well-known typology, some authors recently proposed to distinguish between continuous and sporadic or episodic or discontinuous sources (Withers and Jarvie, 2008; Badruzzaman et al., 2012).

\subsubsection{POINT SOURCE}

Continuous PS emissions are subject to few variations with time. This is the case for aquaculture (Phan et al., 2009; Sindilariu et al., 2009; Amirkolaie, 2011) and wastewater treatment plant (WWTP) discharges under normal conditions (dry weather), which consist in relatively constant volumes and total nitrogen concentration (Carey and Migliaccio, 2009; Igbinosa and Okoh, 2009; Graham et al., 2010).

On the other side discontinuous PS emissions depend on various parameters. An example in rural area is the access of animals to stream with possible in-stream defecation representing a significant source of $\mathrm{N}$ with herd crossing the river (Collins et al., 2007; Davies-colley et al., 2004). Other discontinuous PS in towns are combined sewage overflows (CSOs) discharging directly diluted wastewater when flow exceeds the system capacity during heavy rainfall events (Kim et al., 2007; Bernhardt et al., 2008). CSOs can happen from few times a year (Bremerton CSO Annual Report, 2014) to more than 50 times a year in towns where no infrastructure improvement have been made (Edmonton CSO Control Strategy, 2000; USEPA, 2009). If many programs have been conducted to reduce this pollution for nearly thirty years, it still remains a problem for most of urbanized areas with no separate sewer system, as remediation represents large financial investments. Furthermore, illicit connections (especially in developing countries) can cancel the benefits from a separate sewer system and create similar conditions than combined systems (Li et al., 2013). 


\subsubsection{Non-POINT SOURCES}

Continuous NPS emissions are diffused and take different pathways to reach streams. This is the case for on-site sanitation facilities (cesspools, septic tanks, and pit latrines) and leaky sewer, discharging contaminated wastewaters in soils and groundwater with poor removal of nutrients (Reay, 2004). Amounts and frequency of release depends on daily human excreta and water use, which are relatively constant. However, in a recent review, Bernhardt et al. (2008) showed that $\mathrm{N}$ loads from these systems can be retained or accumulated in soil profiles during very dry weather, whereas they are directly routed to groundwater during wetter conditions, when connectivity of hydrological flow path is high. Thus, this source can be considered as "semi-continuous," as it is not directly affected by rainfall events but rather by water table depth and soil water content.

Discontinuous NPS emissions are the most complex sources because of the need for both availability and transport to reach streams. This is the case for fertilizer spreading, animal excreta (from livestock on grasslands and wildlife), manure or biosolids. Mineral fertilizers, manure (animals waste), and biosolids (treated sewage sludge) are spread at plot scale during specific periods of the year. Depending on agricultural system, crop rotation, farmers practices or regulatory constraints, quantities can differ (Sheriff, 2005; Thompson et al., 2007; Wei et al., 2009). N mineral fertilizers are directly usable by vegetation but can also be exported easily in large amounts if climatic hazard occur, both by surface (Masetti et al., 2008; Liang et al., 2011) and subsurface run-off. Home garden fertilization is controlled by similar factors, but also by social and psychological ones. For example, maintaining a lawn (and fertilizing it) is an avenue to engage with one's neighbors, to fulfill expectations of what it means to be a positive member of a community (Carrico et al., 2012). N losses from organic fertilizers follow different dynamics, as organic matter mineralization is a limiting factor of $\mathrm{N}$ export. Generally, nitrogen derived from organic matter accumulates in soil profile during dry periods and is exported during wet periods (Rimski-Korsakov et al., 2004; Mantovi et al., 2006). Finally, animal excreta directly produced on grasslands are generally considered like organic fertilizers, with calculation of density and time spent by animals in the field (Di and Cameron, 2000). However, the impact may be higher in this case than for organic waste application because of a congregating phenomenon and nutrient supply at times of low level uptake by plants (Hubbard et al., 2004; McGechan and Topp, 2004).

For non-impervious disposal sites, landfill leachates may vary in quality and quantity depending on many factors such as site age, precipitation, evapotranspiration, temperature, waste type, and composition (Oman and Junestedt, 2008; Renou et al., 2008). Leachates may reach groundwater slowly and consequently affect surface waters with a high delay in normal conditions. 


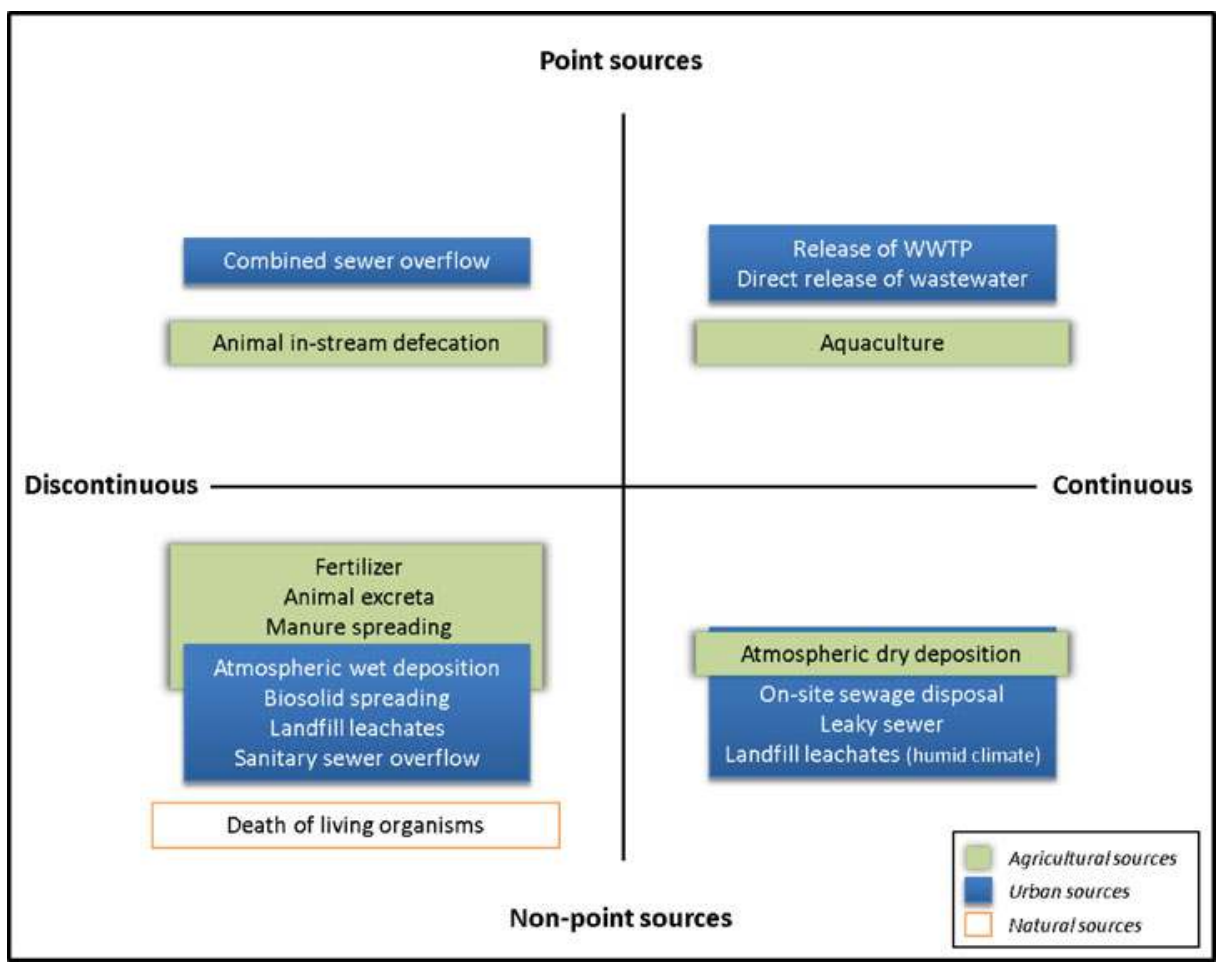

FIGURE 1. Classification of $\mathrm{N}$ sources (WWTP: Waste Water Treatment Plant).

During wet weather, leachate can however affect water quality in a very short time, when surface runoff occurs in large volumes (Marques, 2007; Mangimbulude et al., 2009). Under humid climate, landfill leachate can also be considered as a continuous NPS.

Besides nitrate export from agricultural spreading and landfill leakages, nitrous oxides and ammonia can be emitted in air by natural ecosystems and human activities (transportation, agriculture, industries, and waste) but they can be deposited to soils and rivers by both wet and dry input (Asman et al., 1998; Carrillo, 2002; Paerl et al., 2002). In some areas, inorganic nitrogen deposition seems to be the primary factor of eutrophication (Bergstrom and Jansson, 2006). Dry input is however a continuous NPS, because there is always deposition, even if quantities vary with time. Finally, the decomposition of living organisms after their death could also be considered as non-negligible releases of nitrogen (Hättenschwiler et al., 2005; Duffy et al., 2007). Based on such classification of N sources, Figure 1 is proposed to illustrate the differences between type and origin of $\mathrm{N}$ in watersheds.

As shown on Figure 1, nitrogen source types depend on spatiotemporal factors: climatic hazards, dysfunction of infrastructures, animals/human mobility... . Urban sources generate continuous wastes which are the most 
controllable if appropriate investments are made. On the contrary, agricultural sources are associated with professional practices and a way to reduce nitrogen sources should logically be the livestock pressure decrease on the watersheds but the economic viability of farms must be taken into consideration. Furthermore, agricultural sources are subject to multifactorial explanation of $\mathrm{N}$ export: the wide context diversity compared to urban areas implies many research needs to reach a good understanding of $\mathrm{N}$ dynamics in landscape, and to prioritize remediation actions.

PS directly affect river water quality and their impact can be locally important compared to NPS as they do not benefit of natural remediation before reaching the stream. On the other hand, NPS are driven by several external factors, which can have mixed effects before reaching streams.

In the following sections, two condition groups are considered within watershed boundaries: (1) "normal conditions" defined by infrastructure routine functioning, dry weather, stable discharge and constant population; (2) "exceptional conditions" defined by rainfall event and thus unstable discharge, possibly strengthened by high variation of population, e.g., during touristic period, when the population can highly increase in rural coastal areas.

\section{VARIABILITY OF N EXPORT}

$\mathrm{N}$ export can be defined in different ways depending on the studied scale. For each source, $\mathrm{N}$ produced under different forms is transported more or less quickly through one of three water pathways: surface runoff (also called overland flow), subsurface runoff (also called interflow or lateral flow), and infiltration to groundwater. Surface runoff can affect very quickly the river water quality (minute, hour), while export delays associated with subsurface and groundwater flows are, respectively, intermediate (hour, day) and long/very long (likely years). Thus, $\mathrm{N}$ concentrations in rivers depend both on $\mathrm{N}$ sources on the watershed, and on the ratio of export through the 3 flow paths (with their respective $\mathrm{N}$ load), but also on $\mathrm{N}$ transformations in the landscape before reaching the stream, and then on in-stream transformations by biological activity.

\subsection{Drivers of N Export Depending on N Sources}

The amount of $\mathrm{N}$ exported can widely vary depending on land use, $\mathrm{N}$ availability in soil, soil column characteristics, hydroclimatic variability, and human activities and practices (Table 1). 


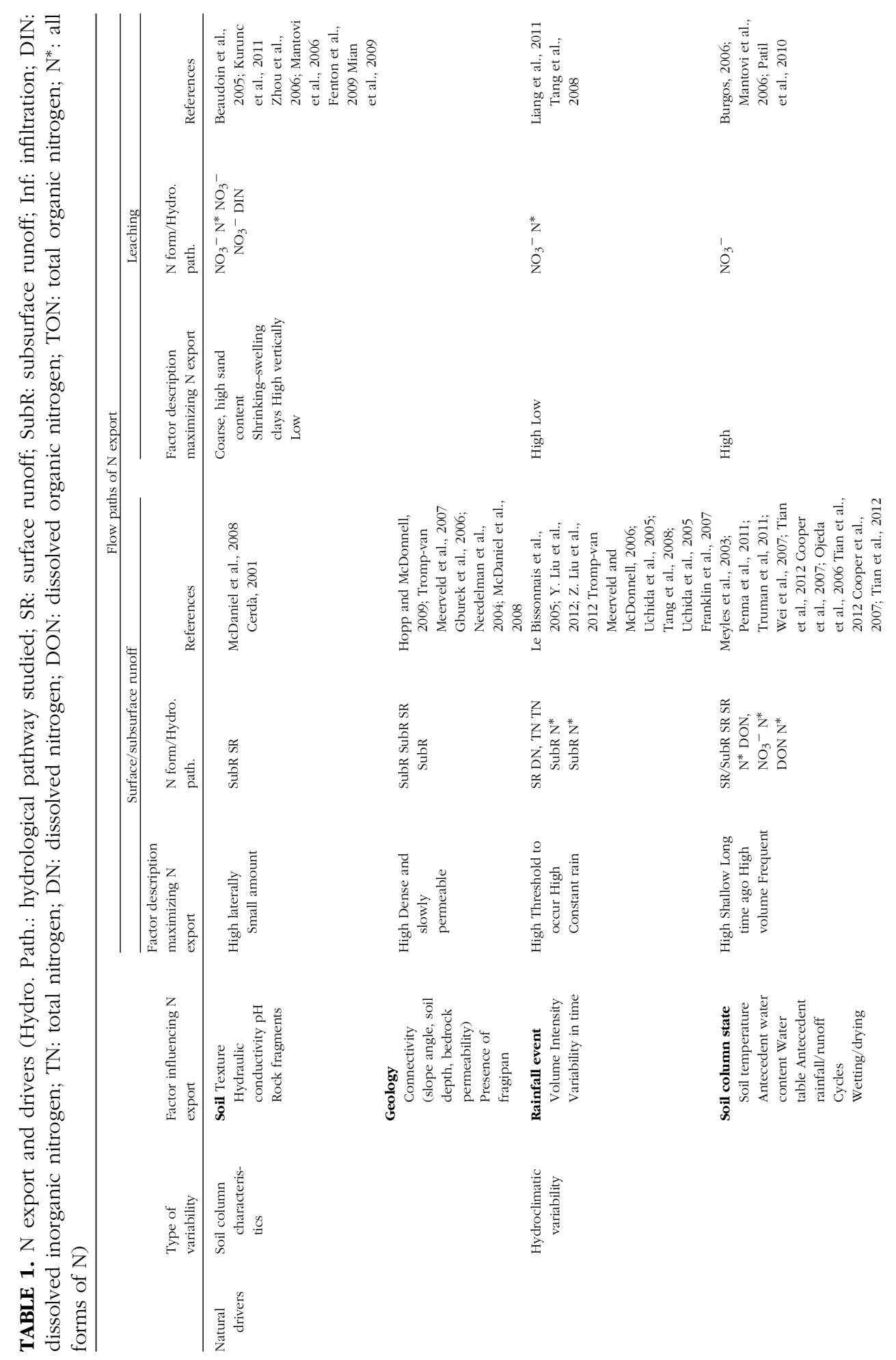


WI

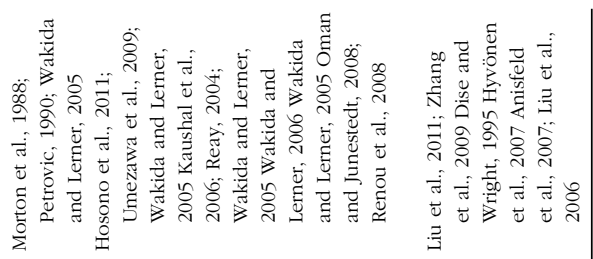

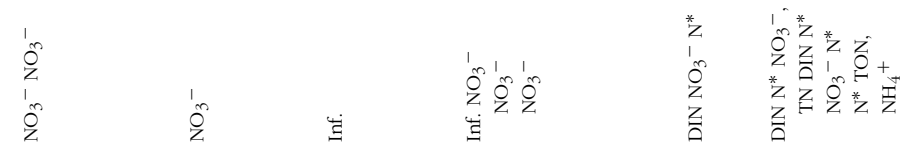

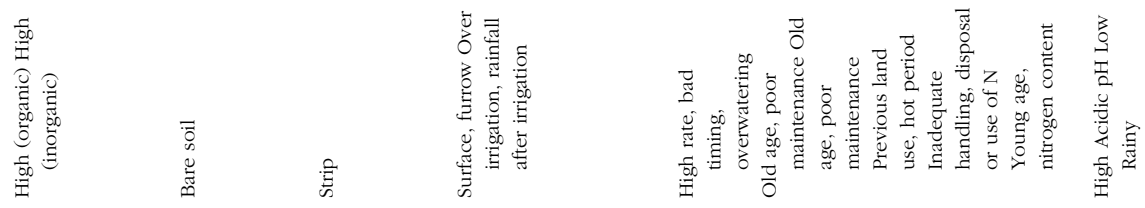

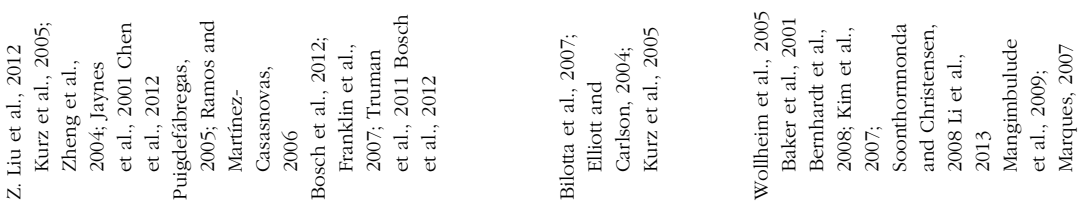

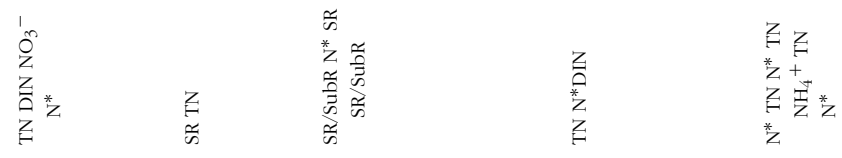

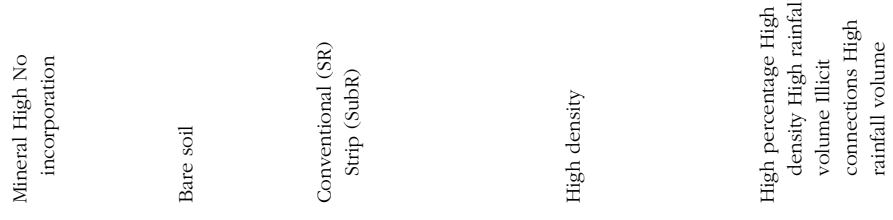

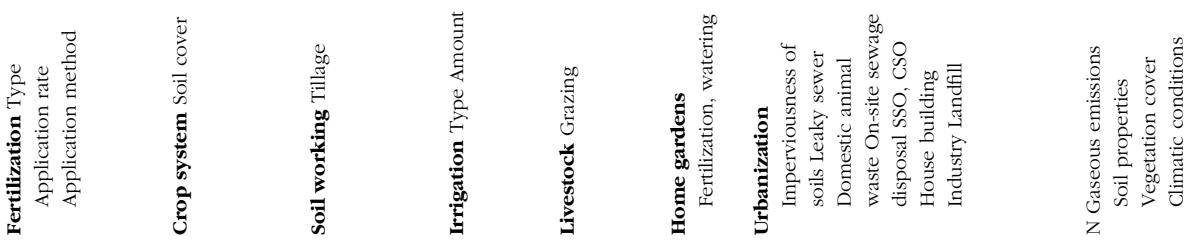

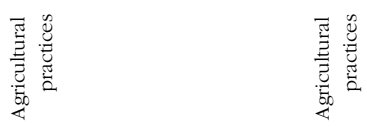

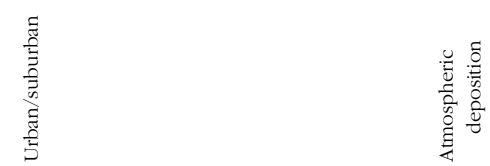

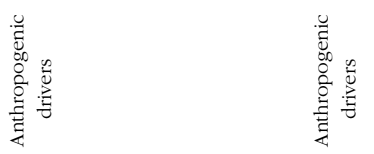




\subsubsection{NATURAL Drivers}

3.1.1.1 Soil Column Characteristics. The soil column characteristics determine the ability to $\mathrm{N}$ export. High nitrate leaching is generally observed under coarse-texture soils, with high sand content. Nitrate concentration in leachate is primarily affected by soil type. Beaudoin et al. (2005) observed concentrations ranging from $31 \mathrm{mg} / \mathrm{L}$ in deep loamy soils up to $92 \mathrm{mg} / \mathrm{L}$ in shallow sandy soils in Northern France. Zhou et al. (2006) found at laboratory scale using a soil column, higher values in sandy loam soils and lower ones in clay loam soils. In a vast study over 161 wells in Turkey, Kurunc et al. (2011) confirmed that nitrate leaching hot spots are generally associated with high sand content in surface soil. Indeed, coarse texture is associated with high saturated vertical permeability $\left(\mathrm{K}_{\mathrm{S}}\right)$ and less water holding capacity, thus letting short time for denitrification to occur (Fenton et al., 2009). On the contrary, losses in runoff are enhanced by fine texture. In a modeling approach, Panagopoulos et al. (2007) have shown that rank of sensitivity of TN losses by surface runoff was silty-clay-loam $>$ silty-loam $>$ clay $>$ loamy $>$ sandy-loam $>$ sandy whereas sensitivity to leaching was sandy $>$ loamy $>$ sandy-loam $>$ silty-loam $>$ silty-clay-loam $>$ clay. However, shrinkingswelling of clays can also create fast drainage conditions (Mantovi et al., 2006). Rock fragments in the field also play a role in increasing infiltration. Their presence in a small amount can thus increase the runoff risk (Cerdà, 2001). In acid soils, less ammonium adsorption can also lead to leaching of this form of nitrogen, whereas nitrate is generally considered as the only solute which can leach (Mian et al., 2009). A high horizontal $\mathrm{K}_{\mathrm{s}}$ associated with fragipan presence in the soil column (i.e., subsurface layer slowly permeable) can enhance subsurface runoff and even lead to a flashy hydrological events, when this flow pathway is of major importance (McDaniel et al., 2008). Hopp and McDonnell (2009) and Tromp-van Meerveld et al. (2007) identified connectivity (related to the subsurface layer characteristics, i.e., slope angle, bedrock permeability, and soil depth) as a key element of subsurface runoff. A presence of fragipan can also increase the possibility of saturation-excess surface runoff to occur, by significantly reducing the depth between saturated layers in soil surface (Needelman et al., 2004; Gburek et al., 2006).

3.1.1.2 Hydroclimatic Variability. Hydroclimatic variability drives N export at the plot scale depending on both the rainfall event characteristics and the "watershed state," i.e., antecedent conditions favorable to export. In the Bourville catchment (France), Le Bissonnais et al. (2005) found poor correlation between rainfall volume and runoff volume for a wide range of soil antecedent conditions, but a good correlation for rainfall with similar antecedent conditions. Rainfall amounts also showed positive linear correlations with runoff $\mathrm{N}$ losses from agricultural plots (Y. Liu et al., 2012). Furthermore, a constant rainfall in time seems to produce higher losses than a variable rains (Franklin et al., 2007). Once rainfall reaches a threshold 
value, subsurface flow occurs (Uchida et al., 2005; Tromp-van Meerveld and McDonnell, 2006) and can transport high nutrient quantities. The subsurface flow volume is then function of rain intensity and duration (Uchida et al., 2005). Finally, according, respectively, to Gu and Riley (2010) and Liang et al. (2011), low frequency, heavy rainfall are the most hazardous conditions for loss by leaching. Nevertheless, Tang et al. (2008) showed that a high intensity of rainfall can produce negligible compared to surface runoff, and inversely for low intensity rainfall. Regarding watershed state, antecedent water content seems to play a major role in surface runoff production (Wei et al., 2007; Truman et al., 2011). Meyles et al. (2003) showed very small increases in stream discharge during watershed dry state, but significantly higher discharge rates during the wet state. In an alpine headwater catchment, high runoff ratios (surface and subsurface flows) occurred during wet antecedent conditions, when a soil moisture threshold value of $45 \%$ was exceeded in the first $30 \mathrm{~cm}$ (Penna et al., 2011). Moreover, irrigation practices can greatly increase the "natural" wetness of the soil. Nitrogen availability in soil surface can also be limited, depending if it has already been flushed many times. Cooper et al. (2007) found that the release of nitrate is mostly influenced by the time between the last flush of soil and the rewetting of the $\mathrm{H}$ horizon. In a study on nitrogen losses in runoff waters from plots treated with sewage sludge, the first five rainfall events represented the major part of nitrate and ammonium export on 14 events (80.6\% to $90.5 \%$ of cumulated loads) (Ojeda et al., 2006). In forested drained area, subsurface flow seems to be influenced by water table depth and antecedent precipitation for nitrate, and frequency of wetting/drying cycles for dissolved organic nitrogen (Tian et al., 2012). Leaching is influenced by drainage and availability of nitrogen in soils. During dry periods, high temperature induces high mineralization rate of organic nitrogen (optimum between 30 and $35^{\circ} \mathrm{C}$ ), and thus nitrate availability (Burgos, 2006). Concentrations can reach up to $300 \mathrm{mg} / \mathrm{L}$ in soil water during warm period, in organically fertilized fields (Mantovi et al., 2006). However, most of the drainage occurs during wet periods. A modeling of these mechanisms in Northern Europe in a context of climate change showed a great complexity. The increase in heavy rainfalls frequency should then increase nitrate leaching, whereas soil warming could reduce it through an increase of evapotranspiration (Patil et al., 2010).

\subsubsection{ANTHROPOGENIC DRIVERS}

3.1.2.1 Agricultural Practices. Agricultural practices are widely involved in nitrogen export and many works have been carried out during the last decades. The application rate of fertilizer is one of the most important factors of $\mathrm{N}$ export. High rates of organic or inorganic fertilizer applied on fields induce large loss in surface, and subsurface runoff and by leaching (Goulding et al., 2000; Jaynes et al., 2001; Daudén et al., 2004; Decau et al., 
2004; Zheng et al., 2004; Kurz et al., 2005; Liang et al., 2011). A poor knowledge of $\mathrm{N}$ content in the soil can partly explain overfertilization practices (Thompson et al., 2007). Because of higher mobility, conventional mineral fertilizers are more susceptible to be exported by rainfall, and thus present higher risk than organic or slow-release fertilizers (Z. Liu et al., 2012). Fertilizer incorporation into soil instead of aerial spreading can reduce loads in surface runoff. A bare soil increases the risk of nitrogen export in all water pathways, because of easier drainage, less transpiration by plants, and less N absorption (Beaudoin et al., 2005; Puigdefábregas, 2005; Ramos and Martínez-Casasnovas, 2006; Gabriel et al., 2012). Thus, cover crop during post-harvesting periods is needed to reduce the risk of $\mathrm{N}$ export. Depending on crop rotation, nitrate concentrations in soil can vary widely. For example, Beaudoin et al. (2005) observed a lower concentration with a sugarbeet-wheat rotation $(38 \mathrm{mg} / \mathrm{L})$ than for a pea-wheat rotation $(66 \mathrm{mg} / \mathrm{L})$. However, considering the variety of possible rotations, this factor is not indicated in Table 1. Monoculture, by reducing crop yield (Smith et al., 2008) can also increase export of nitrogen compared to diversified crop production. Bosch et al. (2012) found that strip-till practice increased infiltration compared to conventional tillage, increasing nitrogen export via subsurface losses. In surface runoff, even if strip-till systems lose more soluble fractions than conventional ones, TN losses are lower (Franklin et al., 2007). Overirrigation leads to large drainage, which is the primary factor of $\mathrm{N}$ export by leaching. It also moistens the soil profile, which can orient biogeochemical processes and increase $\mathrm{N}$ availability. Thus, many studies reported high losses by leaching under irrigated fields (Daudén et al., 2004; Feng et al., 2005; Vázquez et al., 2006). Irrigation modes may have an impact on water uptake uniformity and efficiency by crops (Hassanli et al., 2009). Livestock grazing can considerably increase loss by surface runoff, especially with higher animal densities. Defoliation reduces soil protection against rainfall and increases risks of crusting (Elliott and Carlson, 2004; Bilotta et al., 2007). Treading damage increases the compaction of soil especially for fine-texture soils and during wet periods (Bilotta et al., 2007). Finally, high livestock densities produce a large amount of nutrients which is easily transported by runoff (Kurz et al., 2005).

3.1.2.2 Urban/Suburban Sources. In urban, suburban and rural landscapes, several others sources are involved in $\mathrm{N}$ export depending on the specific land use. Similarly to agricultural land, N export from home gardens increases with fertilization and overwatering (Morton et al., 1988; Petrovic, 1990; Wakida and Lerner, 2005). A high percentage of impervious soils increases surface water runoff potential and decreases $\mathrm{N}$ retention (Wollheim et al., 2005). Even if $\mathrm{N}$ loads are deposited in small amount on these surfaces, a great volume of water may increase $\mathrm{N}$ export significantly (Brabec 
et al., 2002). Kojima et al. (2011) and Baker et al. (2001), respectively, identified road dust and pet waste as majors deposited $\mathrm{N}$ source on impervious surfaces. In developing countries, open defecation may be a significant $\mathrm{N}$ source in surface runoff. However, its impact has not been directly investigated yet. Other sources of $\mathrm{N}$ in surface runoff are discharges from sewage overflows (CSO or SSO), responsible of high nutrients export via surface runoff even if not frequent (USEPA, 2004). Sanitary sewage is the major contributor of ammonium for CSO (Soonthornnonda and Christensen, 2008). Kim et al. (2007) observed high TN load during sewage overflow events in a small Korean urban catchment. Concerning groundwater contamination, Wakida and Lerner (2005) reported that nitrate concentrations in some urban aquifers can be similar or even greater than those in agricultural areas. They identified wastewater disposal as the major source. Septic tank and similar on-site sanitation systems are a common practice in both developed and developing countries. Population and system density, improper design, poor maintenance, and shallow water tables are factors of groundwater pollution (Wakida and Lerner, 2005). Reay (2004) observed N fluxes from such areas similar to the lower values reported for agricultural lands in Chesapeake Bay. In residential areas of the Blue River, Kaushal et al. (2006) found that about $20 \%$ of the annual $\mathrm{N}$ export from developed tributaries was derived from septic systems, and more than 50\% during touristic season for one site. GIS-based monitoring and isotopic analysis suggested that wastewater via severe sewer leakages was the major source of nutrient contaminants in Metro Manila and Jakarta urban areas (Umezawa et al., 2009). Similar results were found in urban parts of Taipei Basin (Hosono et al., 2011). In sub-Saharan Africa mega-cities, more than $60 \%$ of wastewater is disposed via onsite sanitation systems, sometimes without any treatment, and can represent half the total precipitation entering these urban areas (Nyenje et al., 2010). Despite such importance, only few studies estimate this $\mathrm{N}$ input (Wakida and Lerner, 2005). Landfills are great sources of $\mathrm{N}$ in peri-urban/rural areas. Young landfills have generally higher potential for $\mathrm{N}$ release in groundwater, but the load is still important in intermediate and mature ones (Renou et al., 2008). The composition of wastes and the hydro-climatic variability play obviously a role in $\mathrm{N}$ losses amounts. $\mathrm{N}$ export is higher during wet periods because of great drainage volume, while TN concentrations are higher during dry periods (Mangimbulude et al., 2009). Leaching to groundwater constitutes the main $\mathrm{N}$ loss pathway, while heavy rainfall also leads to high losses via surface runoff (Marques, 2007; Mangimbulude et al., 2009). Indeed, landfills are generally open wastes dump in developing countries. In developed countries, landfill roofing avoids surface runoff in adapted infrastructures. House building is a source comparable to grassland ploughing in temperate climates, especially if previous land use lead to high nitrogen content and if building took place during the warm period (Wakida and Lerner, 2006). 
Finally, Wakida and Lerner (2005) underlined that inadequate handling, disposal or use of $\mathrm{N}$ compounds in industry (leaky tanks for example) can lead to groundwater contamination.

3.1.2.3 Atmospheric Deposition. Atmospheric deposition is classified here in anthropogenic sources because quantities of $\mathrm{N}$ per surface units are now widely more important that under pristine conditions (Aber et al., 2003; Galloway et al., 2008). Indeed, Dise and Wright (1995) have shown that below a threshold of $10 \mathrm{~kg} / \mathrm{ha}$ of $\mathrm{N}$ input, there is no leaching under European forests. Deposition is an indirect anthropogenic source of Nitrogen in water as the first step is the emission in the atmosphere of $\mathrm{N}$ gaseous forms mainly by agricultural practices and urban traffic (Luo et al., 2003; Zhang et al., 2009; Liu et al., 2011). This $\mathrm{N}$ is then deposited by wet or dry deposition in (short-time transport) or out (long-time transport) of the hydrologic unit of the emission (Luo et al., 2003; Holland et al., 2005). Dise and Wright (1995) found that nitrate leaching in European forests is associated with strong $\mathrm{N}$ inputs and low soil pH. Harriman et al. (1998) found similar results by comparing $\mathrm{N}$ deposition and river water composition. Dise and Wright (1995) also pointed out that the combination of $\mathrm{N}$-input and soil $\mathrm{pH}$ explained $87 \%$ of $\mathrm{N}$ output-. Furthermore, vegetation cover can be a negative factor for $\mathrm{N}$ export by deposition as canopy intercepts nitrogen deposition thus lowering the loss risks (Hyvönen et al., 2007). Globally, the proportions of wet and dry deposition on watersheds seem to be equal (Lawrence et al., 2000; Holland et al., 2005). However, some authors have shown that deposition can be unsignificant during baseflow and very significant during stormflow (Anisfeld et al., 2007). Similarly, Liu et al. (2006) found that more than 80\% of total $\mathrm{N}$ deposition in the Beijing area occurred during the rainy season, following fertilizer application.

Through this review of factors enhancing $\mathrm{N}$ export depending on each $\mathrm{N}$ source, it is shown that all human activities are associated with more or less export of exceeding nitrogen. This export can be controlled by natural drivers, which are primarily related to hydroclimatic conditions and local watersheds characteristics. It can be relatively easy to assess what are best practices at a small scale, for example by simulating rain on two agricultural plots under different conditions of tillage and fertilization. However, the site-characteristic specificities must be taken into consideration before drawing general conclusions. Furthermore, hydroclimatic variability is very important in "real" (non-simulated) situations. Particularly, water pathways must be well known to assess qualitatively and quantitatively the nitrogen forms exported at different time-scales. For example, practices reducing $\mathrm{N}$ export via surface runoff (rapid transport, especially due to heavy rainfalls) can also enhance $\mathrm{N}$ export via leaching (long transport). Based on this statement, hydrologists and biogeochemists should join their efforts to obtain a 
better understanding of both hydrological mechanisms and nitrogen export, especially concerning subsurface runoff (lateral flow) for which uncertainties are the highest. Moreover, factors maximizing N export (e.g., leaky sewers or poor maintenance of on-site disposal) can also make the impact assessment difficult to estimate at the watershed scale.

Regarding the different $\mathrm{N}$ forms involved and depending on the water pathways (Table 1), nitrate is the main form concerned by leaching, even if some authors underline the potential importance of others forms (DON, $\mathrm{NH}_{4}{ }^{+}$). Concerning $\mathrm{N}$ export via surface and subsurface runoff, TN can also be considered. Thus, monitoring at least nitrate and Kjeldahl nitrogen could greatly enhance the understanding of export phenomenon whatever the various situations.

\section{$3.2 \mathrm{~N}$ in Drainage Network Depending on N Sources, Transportation and Transformation}

At the watershed scale, the difficulty to monitor and acquire data on watersheds limit the interpretation of all factors studied in the previous section. $\mathrm{N}$ concentrations in river depend on land use and hydroclimatic variability. Land use determines types of $\mathrm{N}$ sources, sensitivity to $\mathrm{N}$ export, and transformations across the landscape, like buffering capacity (i.e., the potential to retain/remove nitrogen). Hydroclimatic variability determines flood regime, environmental conditions and rainfall events, which in turn affect the response of landscape. Additionally, evolutions in land use and anthropogenic activities have an effect on the variability of $\mathrm{N}$ concentrations in rivers: population variation (e.g., tourism), agricultural practices (e.g., fertilization) and land use evolution (e.g., deforestation). Figure 2 proposes a representation of all influences on $\mathrm{N}$ export at different time scale, from rainfall event to decades. In this review, variations of $\mathrm{N}$ concentrations in rivers are studied at the annual scale. Because the concept of season is very dependent on the geographic position, only wet and dry periods are considered, assuming that in many parts of the world both are relatively well differentiated.

\subsubsection{LAND USE}

The primary factor of $\mathrm{N}$ export at the watershed scale is the land use. "Forested," "urban/suburban," or "agricultural" are usually employed to characterize a watershed type having a great proportion of one of these patterns. A fourth type of watershed is "rural/lightly developed," corresponding to a mix of land use mostly dominated by agriculture. Undisturbed forested catchments are generally used as a reference for pristine environment. Even if anthropogenic atmospheric deposition can be involved in $\mathrm{N}$ export from these watersheds, many studies have shown higher $\mathrm{N}$ concentrations in agricultural and urban/suburban catchments (Chang, 2008; Mulholland et al., 


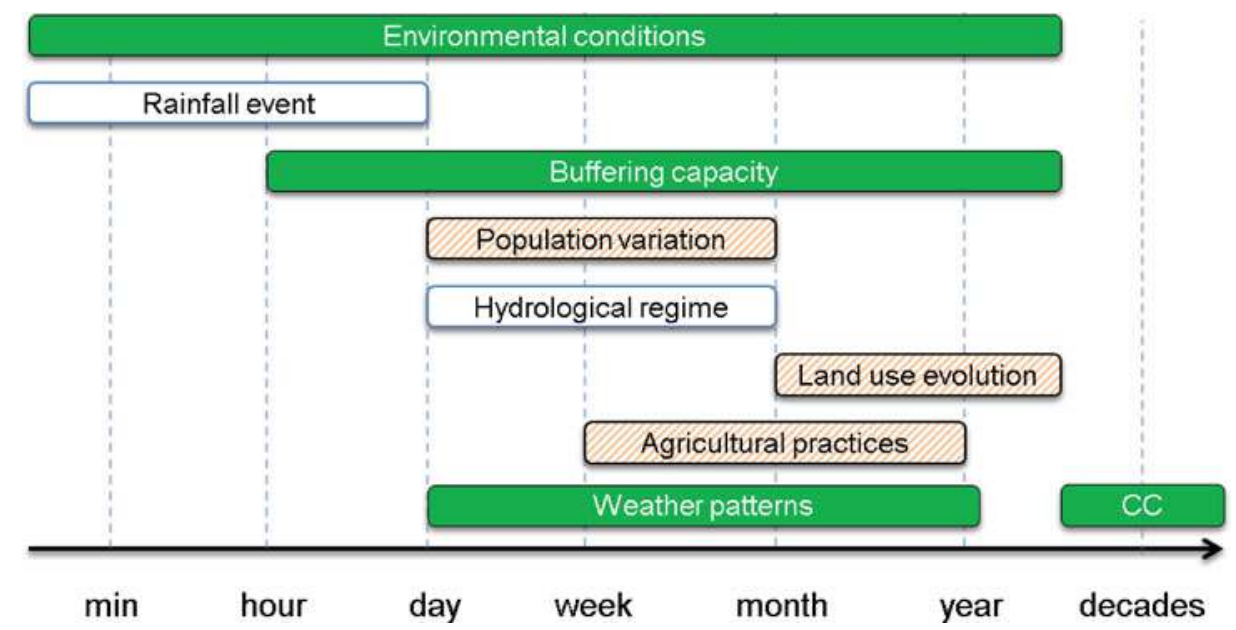

FIGURE 2. Time scale of environmental change and human practices (CC: climate change).

2008; Buda and Dewalle, 2009; Burns et al., 2009; Li et al., 2009; Kaushal et al., 2011). TN concentrations are generally positively correlated with impervious/urbanized soil (Chang, 2008; Shields et al., 2008) and agricultural fields percentages (Donohue et al., 2005; Lassaletta et al., 2009). However, the impact of land use depends also on the watershed characteristics. For example, the percentage of forest can be related to very low $\mathrm{N}$ concentrations, when the contribution of base flow to the total flow is important. Conversely, it can have no effect if the watershed is characterized by high stream slopes, fine soil texture and high runoff potential (Norton and Fisher, 2000). Similarly, it seems not possible to associate greater N loads with a given type of unforested watershed, because of the variety of contexts in each type of watersheds. For example, lightly developed catchments can deliver twice the $\mathrm{N}$ load of urban catchments because of a large number of on-site disposal (Shields et al., 2008), and big towns can give similar N load per area unit that agricultural areas (Wakida and Lerner, 2005).

\subsubsection{Hydroclimatic Variability}

3.2.2.1 Stream Order. The second factor of $\mathrm{N}$ export at the watershed scale is the hydroclimatic variability. Alexander et al. (2007) found that firstorder streams from headwaters contribute approximately to $65 \%$ of $\mathrm{N}$ fluxes of the second-order streams and $40 \%$ of the flux of 4th- and higher-order streams. Thus, agriculture and urban impacts must be particularly considered in these areas (Freeman et al., 2007; Elmore and Kaushal, 2008). Headwaters are also more reactive concerning $\mathrm{N}$ transformations, particularly for ammonium forms (Peterson et al., 2001).

3.2.2.2 River Morphology. The linearization of stream decreases the residence time of nitrate by increasing flow velocities and streams restoration 
is therefore a possible way to reduce nitrogen export from watersheds (Chen et al., 2011). Craig et al. (2008) reviewed stream restoration strategies for reducing river nitrogen loads and proposed to promote actions that increase in-stream carbon availability, contact between the water and benthos, and connections between streams and adjacent terrestrial environments. However, there are many uncertainties on the efficiency of these actions. For example, Wagenschein and Rode (2008) calculated a possible reduction of $\mathrm{N}$ loads by only $5.4 \%$ on the Weisse Elster River (Germany).

\subsubsection{Contribution of (Sub-)Surface Runoff and Groundwater Flow} to the River Flow. The hydroclimatic variability drives the contribution of each hydrological component (surface, subsurface runoff and groundwater flow) to the total flow. In average, $\mathrm{TN}$ concentrations are much lower during dry period than during wet period for catchments with impervious bedrock (Shrestha and Kazama, 2007; Burns et al., 2009; Li et al., 2009). This difference is generally attributed to a lower groundwater contribution to total flow during this period (Schilling and Zhang, 2004; Donohue et al., 2005). Indeed, recent studies have shown the primary significance of groundwater in controlling stream water nitrate concentrations $\left(\left[\mathrm{NO}_{3}{ }^{-}\right]_{\mathrm{sW}}\right.$ ) (Ruiz et al., 2002a, 2002b; Blanco et al., 2010). Molenat et al. (2008) proposed a scheme identifying the water table dynamic and spatial differences in nitrate concentrations in groundwater $\left(\left[\mathrm{NO}_{3}{ }^{-}\right]_{\mathrm{GW}}\right)$ as the main drivers of $\left[\mathrm{NO}_{3}{ }^{-}\right]_{\mathrm{SW}}$ in normal conditions. More generally, Legout et al. (2007) showed that solute transfer in groundwater is not homogeneous, but rather complex and with a two porosity compartment (a slow-mobility and rapid-mobility porosity). Recently, Rouxel et al. (2011) showed that solute transfer via groundwater should be affected by a strong spatiotemporal variability and argued that it must be taken into account in hydrochemical models. However, these mechanism-process studies were made on small headwaters catchments, which may not integrate all types of $\mathrm{N}$ sources and the complexity of water pathways in larger landscape.

Blanco et al. (2010) observed that nitrate in river increases with increasing contribution in groundwater, and suggest that groundwater $\mathrm{N}$ concentration is the main driver to $\mathrm{N}$ export. At the opposite, some authors suggested that surface and subsurface runoffs are a major vector of $\mathrm{N}$ export during rainfall events. Intensively drained agricultural watersheds seem to present a "flashy" response to rainfall events by exporting large quantities via subsurface tile-drain (Tomer et al., 2003; Royer et al., 2006). More than 80\% of agricultural land is drained by surfaces ditches or subsurface tiles in some areas (e.g., Midwestern United states) (Blann et al., 2009), and $\mathrm{N}$ loads in drainage can reach more than $80 \mathrm{~kg} \mathrm{~N} / \mathrm{ha}$ in some cases (Kaspar et al., 2007). Thus, the coincidence of temporal variation in TN concentrations with local seasonal calendar of agricultural activities and rainfall distribution may reflect the influence of rapid flow pathways (Royer et al., 2006; Bu et al., 2010). 
3.2.2.4 Hydrological Regime. Discharges of wastewater treatment plants (WWTP) can have an important effect on $\mathrm{N}$ concentration in streams during some periods of the year. For example, in Blue River watershed, a WWTP discharge represents only $15 \%$ of total annual $\mathrm{N}$ flux but up to $80 \%$ of the N flux during dry period when WWTP discharge becomes significant compared to the river flow (Graham et al., 2010). Similarly, Kaushal et al. (2011) found that wastewater is a major source of nitrate during baseflow conditions in Baltimore urbanized streams, and that its importance decreases with increasing runoff. On the opposite, WWTP discharges can have a very small effect on TN concentrations in river if other sources in the watershed are much more important (Merseburger et al., 2005, 2011; Burns et al., 2009). Furthermore, watersheds can show different global behaviors during the year depending on the main land use. In the Chesapeake Bay watershed, most of nitrate is exported at low to moderate flow ( $<1 \mathrm{~mm} /$ day $)$ from forested, lightly developed and agricultural catchments, but at high flow ( $>1 \mathrm{~mm} /$ day) from urban catchments (Shields et al., 2008). Extreme events (associated here to "exceptional conditions") can also be of major importance for $\mathrm{N}$ export from watersheds. In many watersheds, a large fraction of $\mathrm{N}$ export can occur only in a limited period of the year, during rainfall periods and snowmelt events (Borah et al., 2003; Royer et al., 2006; Sebestyen et al., 2008). For example, Borah et al. (2003) observed in Illinois that added nitrate fluxes in stormflow from March to June can reach nearly $40 \%$ of the average annual flux during a dry year and 100\% during a wet year. In a small forested Mediterranean catchment, Bernal et al. (2002) found that $80 \%$ of the annual nitrate flux occurred during a single storm event, because of lower $\mathrm{N}$ retention, and pulses of nutrient cycling after a long dry period. In river, particulate nitrogen from diverse land use settled in riverbed, but can be resuspended during high flow (Schulz et al., 2003; Donohue et al., 2005). In urban watershed, no significant differences in nitrate concentrations is generally found between baseflow and stormflow, indicating that fluxes are higher during storm events (Taylor et al., 2005; Wollheim et al., 2005; Kaushal et al., 2008). Furthermore, urban watersheds are more submitted to extreme hydrological conditions (droughts and storms) compared to agricultural and forested catchements (Paul and Meyer, 2001). Borah et al. (2003) studied the nitrate dynamics in river in three agricultural catchments (from 98 to $932 \mathrm{~km}^{2}$ ) during storm events, and showed an inverse relationship with water discharge during intense storms and a weak relationship during less intense storms. They suggested that this was due to a mobilization of nitrate-rich porewater during light rainfall events and dilution during heavy rainfall events.

Finally, a recent study on three French rivers over 27 years, Baurès et al. (2013) showed that nitrate fluxes increase with discharge and become constant at very high flow, indicating a mass-limitation until a discharge threshold value is reached. $\mathrm{N}$ sources also have different effects during storm events, depending on land use and period. For example, atmospheric deposition 
contribute up to $30 \%$ of $\mathrm{N}$ load during stormflow in forested catchments (Sebestyen et al., 2008; Buda and Dewalle, 2009), while it may be higher in urban catchments (>50\%) (Anisfeld et al., 2007; Buda and Dewalle, 2009; Burns et al., 2009).

\subsubsection{N TRANSFORMATION}

3.2.3.1 Denitrification. The vicinity of $\mathrm{N}$ sources to river seems to be also an important factor of $\mathrm{N}$ delivery to large rivers (Alexander et al., 2000). If some parts of the watershed are particularly sensitive to $\mathrm{N}$ export, some other parts can attenuate $\mathrm{N}$ loads. In fact, more than $50 \%$ of inputs can "disappear" before reaching the outlet (Seitzinger et al., 2006; Alexander et al., 2007). Some $\mathrm{N}$ compounds are either retain in temporary sinks (e.g., plant growth uptake) or turned to gaseous forms such as $\mathrm{N}_{2} \mathrm{O}, \mathrm{NO}$, or $\mathrm{N}_{2}$ that will be transformed into aerosol phase compounds (ammonium and nitrate) and can fall back partly with precipitation (Sutton et al., 2011). Riparian zones are recognized as very important areas involved in these processes (Ranalli and Macalady, 2010) and "hot spots" of $\mathrm{N} \mathrm{removal} /$ retention are found especially at the interface between coarse permeable material and fine organic rich material in the subsurface soil layers (McClain et al., 2003; Vidon et al., 2010). In this way, Wohlfart et al. (2012) found for example that the fraction of coarse texture and organic soils in an intensively managed agricultural watershed has a major influence on $\mathrm{N}$ export. Moreover, a fraction of $\mathrm{N}$ input is lost in stream by denitrification via the exchange between water column and hyporreic sediments (Seitzinger et al., 2006; Mulholland et al., 2008). Thus, the retention is higher in tributaries than in mains stream (Chen et al., 2011), and decline from upstream to downstream with increasing stream size (Alexander et al., 2000). Retention and denitrification are also more efficient in rural than in urban/suburban area (Groffman and Crawford, 2003).

The efficiency of buffer zones is also very dependent of hydroclimatic variability. In riparian areas, important amounts of nitrogen can be retained/remove during specific period of the year, decreasing nitrogen flux in water. But these zones can be bypassed during high flow (Paul and Meyer, 2001) or be inefficient in very dry context, by lack of water to denitrifying microorganisms (Bernal et al., 2012). In the same way, the retention efficiency of sediments is generally inversely proportional to the stream discharge because exchange between water column and sediments is less important during high flow (Royer et al., 2004). However, flooding can increase denitrification by improving contact with microbiologically reactive sediments in some rivers with extensive floodplains or riparian areas (Alexander et al., 2007). In summer and early autumn, macrophyte abundance in river channels can increase $\mathrm{N}$ retention and water residence time (Schulz et al., 2003). In general, processes that have minor consequences at high flow can become significant at low flow, especially during dry periods (Alexander et al., 2007). 
3.2.3.2 Other in Stream Transformations. Improving knowledge about processes controlling in stream $\mathrm{N}$ transformations is critical to assess watershed vulnerability to water quality changes. The relationships between nitrogen concentration and runoff flowrate for watersheds of varying land use have provide a better understanding on how watershed hydrology and land use interactively regulate nitrogen inputs to stream water and downstream aquatic media. For instance, Goodridge and Melack (2012) have determined a hyperbolic relation for nitrate concentration observed in stream water during periods of low runoff (i.e., base flow) and high runoff (i.e., stormflow). They have also observed the contribution of land use nature: in undeveloped watershed, an enrichment of nitrate-runoff relationship was demonstrated, whereas invariance and dilution were found, respectively, for urban watersheds and agricultural watersheds. The seasonal variation in hydrological conditions was found to be the predominant controlling factor of in stream N-transformations (Ohte, 2012). A seasonal evolution between spring (high nitrate/low DOC) and autumn (high DOC/low nitrate) were also shown by Thomas et al. (2014), who proposed a simple linear model for nitrate-DOC relationship in freshwaters in intensive agricultural environments where algae blooms may occur in waterbodies (rivers, lakes and coastal waters). Nowadays, different approaches are proposed a better understanding of nutrient cycling, and are based on ecological theory and stoichiometry (Allen and Gillooly, 2009). According to Ohte (2012), the ecosystem nutrient demand as well as the solute transport capability and in-stream nutrient use and supply are the main factors impacting the seasonal patterns of stream nitrate concentrations.

Concerning DON it was found that headwater streams can quickly convert inorganic $\mathrm{N}$ into organic forms, so that the production of autochthonous DON can represent a substantial transformation of stream $\mathrm{N}$, although the ultimate fate of DON remains unclear (Johnson et al., 2013). Improving our knowledge on the riparian zone role in nitrate attenuation in undisturbed watersheds is a real challenge since these watersheds are very sensitive to land use and climate changes, wildfire, and increases in atmospheric nitrogen deposition (Ranalli and Macalady, 2010).

\subsection{Long Term Studies}

Anthropogenic activities have created complex ecosystem structures, with different land uses and landscapes which determine the flows and the fate of nitrogen reactive forms from local scale (plot) to more extended scale (watershed). Alvarez-Cobelas et al. (2008), analyzed N export rates from 946 rivers in the world, and suggested that spatial and temporal scale are very important to predict $\mathrm{N}$ export, and that regional approaches are more useful 
than global-scale analyses. Furthermore, many authors underlined the necessity to implement high resolution monitoring programs to evaluate both spatial and temporal variability at the watershed scale (Bengraine and Marhaba, 2003; Donohue et al., 2005; Chang, 2008; Bu et al., 2010). Many works have been published concerning long-term studies of $\mathrm{N}$ export, taking into account the global effects of anthropogenic evolution impacts such as climate change. For instance, some studies correlate several nutrients fluxes (C, N, P, Si) with livestock densities increase or with sewage treatment plants (Humborg, 2007). However, the main published results concern modeling works, sometimes integrating both anthropogenic evolutions, land use and climate change. Indeed, even current terrestrial ecosystem models fail to explain some long-term nutrient evolutions (Bernhardt et al., 2005). Other factors such as changes in the chemical composition of atmosphere, soil frost, or interannual climate fluctuations should be taken into account. The high temporal variability in nitrogen concentrations both among catchments and into each site highlights the critical need for long-term networked water quality monitoring to gain a better knowledge of nutrient fluxes evolution (Argerich et al., 2013). The application of models for future land use, integrating the management practices such as organic farming methods, and climate scenarii suggest that riverine $\mathrm{N}$ export is likely to significantly increase both in response to heavier fertilizer use and to annual discharge fluctuations (Han et al., 2009). Some statistical nutrient loss models were developed to simulate the combined effects of climate-change on hydrology, nutrient losses, and nitrogen retention processes at the river basin scale (Andersen et al., 2006). This last study concludes that mean annual TN export from the river basin could increase from the control to the scenario period by $7.7 \%$. Even though a $4.2 \%$ increase in nitrogen retention in the river system was simulated in the scenario, an increase in-stream TN export resulted because of the simulated increase in the diffuse TN transfers from land to surface waters.

Climate change also increase the fractional export of anthropogenic $\mathrm{N}$ inputs to river. The lag effect, soil $\mathrm{N}$ release, and climate change, delaying riverine $\mathrm{TN}$ export reductions with respect to decreases in $\mathrm{N}$ inputs and should be considered in developing and evaluating $\mathrm{N}$ management measures (Chen et al., 2014). Wu et al. (2012) show that global climate change impact on pollution load are relatively greater when compared to future livestock and poultry breeding increases or agricultural population reductions. The effects observed from runoff increment lead to approximately $28.6 \%$ and $22.5 \%$ increases of $\mathrm{TN}$ and $\mathrm{TP}$ pollution load respectively. Generally, the impacts of land-use change have shown insignificant effect due to soil conservation measures, whereas the impacts of rural residential area account for high proportion changes, among which around 5\% related to the increase in livestock and poultry breeding. The largest contribution rate comes from the output of different land use types. 
In the previous paragraphs, we demonstrated that local factors including catchment characteristics and natural disturbance events influence the evolution of $\mathrm{N}$ export. Moreover, synthesis of longterm stream chemistry data from different catchments is valuable to understand these trends. Indeed, a watershed ecosystem is a temporally evolving structure. Measuring how nutrient flux and cycling in both stream and terrestrial ecosystems change through time is crucial for analyzing and interpreting nutrient flux and cycling at the overall watershed-landscape scale. These results also emphasize the importance of site-specific strategies that are relevant for the choice of catchments and sampling schemes. Such information is crucial when considering trends, refinement of existing programs, and establishment of new monitoring sites.

In this section, we showed that nitrogen in rivers depends on a combination of factors described in Section 3.1 (via land use and hydro-climatic variability on the watersheds) but also on $\mathrm{N}$ transformations across the landscape and within the river system. However, all these factors are very difficult to assess together as a watershed is a sum of various land uses and conditions. Therefore, most of studies focus only on some of them to estimate their effect on $\mathrm{N}$ variability in streams. Evaluating accurately the main contributors to total nitrogen export and the effects of "situations at risk" on this export is a hard task depending on local conditions. Generally, modeling is used to combine all possible factors and define strategies for $\mathrm{N}$ export reduction. If it is sufficient to plan mitigation actions at a global scale, the responses given by models are limited by our knowledge of combined factors and by a lack of high frequency data, especially during "situations at risk." Scientists should also join their efforts for a better understanding of variations in $\mathrm{N}$ export at different spatiotemporal scales. Accurate data on watersheds are also needed to associate/dissociate the different anthropogenic influences from other and natural influences.

Nitrate is the main $\mathrm{N}$ compound studied at the watershed scale even if organic compound as much or more relevant in numerous case studies: nitrate and Kjeldahl nitrogen should at least be measured in all routine watershed monitoring.

Furthermore, global change could lead to radical increases of $\mathrm{N}$ export despite the mitigation efforts undertaken by all actors. Therefore, there is an urgent need for a better understanding of spatiotemporal variability of $\mathrm{N}$ export to reduce actual loads and anticipate future changes.

\section{CONCLUSION \& PERSPECTIVES}

This review of $\mathrm{N}$ sources and $\mathrm{N}$ export conditions shows that such environmental and health issues cannot be reduced to simple remediation actions. On one hand, the export of $\mathrm{N}$ is affected by numerous natural 
and anthropogenic factors, which are partly uncertain (e.g., climate) and partly not well known (e.g., hydrological pathways). On the other hand, in-streams $\mathrm{N}$ dynamics at the watershed scale, from rainfall event to intraannual variability is associated with many other factors such as the distribution of land use in the landscape, watershed characteristics, calendar of agricultural activities, etc. Scientific studies on factors promoting $\mathrm{N}$ export (e.g., fertilization rate or type) applied to a wide range of environment allow to establish a large catalog of "best management practices" for different types of $\mathrm{N}$ sources. The application of such practices is a key component for the efficiency of remediation actions and should be widely promoted.

At the watershed scale, some observations on $\mathrm{N}$ concentrations variability and load in stream water are largely assumed by authors (e.g., impact of land use) but some others rather seem to be very linked to the watershed characteristics and to hydroclimatic context. If these observations have major implications in understanding global processes at a large scale, it seems very difficult, for example, to accurately assess the risk under rainy events, for different hydrological conditions in a watershed and at the intra-annual scale. Given the difficulty to accurately monitor water quality at watershed scale, various methods have been proposed to evaluate the effects of anthropogenic activities and the related variability: experimental headwater catchments, $\mathrm{N}$ source tracking, multivariate analysis, interannual comparison, hydrologic separation... . These methods allow many advances in understanding of $\mathrm{N}$ export but the diversity of watersheds and the lack in mechanisms knowledge still remain a difficulty in the analysis of experimental data. Analysis of long-term stream studies from multiple catchments is also a real challenge for trend understanding. These studies reveal that spatial and temporal scales are important to predict $\mathrm{N}$ export, so that high resolution monitoring programs are a real need for a more precise understanding of global variability. Eventually, the increasing use of rapid on site methods for very high frequency monitoring (minute step) of some water quality parameters opens new opportunities. Furthermore, the development of different analytical methods to explain $\mathrm{N}$ export variations should be very useful to take full advantage of the acquired data. Advices in prioritization of remediation techniques could be greatly enhanced by this integrative approach.

\section{ACKNOWLEDGMENTS}

The authors sincerely thank Dr Frédéric Pitois for the proofreading. 


\section{FUNDING}

This work is supported by the French Agence de l'Eau Loire-Bretagne (AELB), the French "Conseil Régional de Bretagne," the French Association Nationale de la Recherche et de la Technologie (ANRT), and Coop de France Ouest.

\section{REFERENCES}

Aber, J. D., Goodale, C. L., Ollinger, S. V., Smith, M.-L., Magill, A. H., Martin, M. E., Hallett, R. A., and Stoddard, J.L. (2003). Is nitrogen deposition altering the nitrogen status of northeastern forests? Bioscience 53, 375-389.

Alexander, R. B., Boyer, E. W., Smith, R. A., Schwarz, G. E., Moore, R. B., and Richard, B. (2007). The role of headwater streams in downstream water quality. J. Am. Water Resour. Assoc. 43, 41-59.

Alexander, R. B., Smith, R., and Schwarz, G. (2000). Effect of stream channel size on the delivery of nitrogen to the Gulf of Mexico. Nature 403, 758-761.

Allen, A. P., and Gillooly, J. F. (2009). Towards an integration of ecological stoichiometry and the metabolic theory of ecology to better understand nutrient cycling. Ecol. Lett. 12, 369-384.

Alvarez-Cobelas, M., Angeler, D. G., and Sánchez-Carrillo, S. (2008). Export of nitrogen from catchments: A worldwide analysis. Environ. Pollut. 156, 261-269.

Amirkolaie, A. K. (2011). Reduction in the environmental impact of waste discharged by fish farms through feed and feeding. Rev. Aquacult. 3, 19-26.

Anbumozhi, V., Radhakrishnan, J., and Yamaji, E. (2005). Impact of riparian buffer zones on water quality and associated management considerations. Ecol. Eng. 24, 517-523.

Andersen, H. E., Kronvang, B., Larsen, S. E., Hoffmann, C. C., Jensen, T. S., and Rasmussen, E. K. (2006). Climate-change impacts on hydrology and nutrients in a Danish lowland river basin. Sci. Total Environ. 365, 223-237.

Anisfeld, S. C., Barnes, R. T., Altabet, M. A., and Wu, T. (2007). Isotopic apportionment of atmospheric and sewage nitrogen sources in two Connecticut rivers. Environ. Sci. Technol. 41, 6363-6369.

Argerich, A., Johnson, S. L., Sebestyen, S. D., Rhoades, C. C., Greathouse, E., Knoepp, J. D., Adams, M. B., Likens, G. E., Campbell, J. L., McDowell, W. H., Scatena, F. N., and Ice, G. G. (2013). Trends in stream nitrogen concentrations for forested reference catchments across the USA. Environ. Res. Lett. 8.

Asman, W. E.H., Sutton, M. A., and Schjorring, J. K. (1998). Ammonia : Emission, atmospheric transport and deposition. New Phytol. 139, 27-48.

Badruzzaman, M., Pinzon, J., Oppenheimer, J., and Jacangelo, J. G. (2012). Sources of nutrients impacting surface waters in Florida: A review. J. Environ. Manage. 109, 80-92.

Baker, L. A., Hope, D., Xu, Y., Edmonds, J., and Lauver, L. (2001). Nitrogen balance for the Central Arizona-Phoenix (CAP) ecosystem. Ecosystems 4, 582-602.

Baurès, E., Delpla, I., Merel, S., Thomas, M.-F., Jung, A.-V., and Thomas, O. (2013). Variation of organic carbon and nitrate with river flow within an oceanic regime 
in a rural area and potential impacts for drinking water production. J. Hydrol. 477, 86-93.

Beaudoin, N., Saad, J. K., Van Laethem, C., Machet, J. M., Maucorps, J., and Mary, B. (2005). Nitrate leaching in intensive agriculture in Northern France: Effect of farming practices, soils and crop rotations. Agric. Ecosyst. Environ. 111, 292-310.

Behera, S., and Panda, R. K. (2006). Evaluation of management alternatives for an agricultural watershed in a sub-humid subtropical region using a physical process based model. Agric. Ecosyst. Environ. 113, 62-72.

Bengraine, K., and Marhaba, T. F. (2003). Using principal component analysis to monitor spatial and temporal changes in water quality. J. Hazard. Mater. 100, 179-195.

Bergstrom, A.-K., and Jansson, M. (2006). Atmospheric nitrogen deposition has caused nitrogen enrichment and eutrophication of lakes in the northern hemisphere. Global Change Biol. 12, 635-643.

Bernal, S., Butturini, A., and Sabater, F. (2002). Variability of DOC and nitrate responses to storms in a small Mediterranean forested catchment Site description of the Fuirosos catchment. Hydrol. Earth Syst. Sci. 6, 1031-1041.

Bernal, S., Schiller, D., Sabater, F., and Martí, E. (2012). Hydrological extremes modulate nutrient dynamics in mediterranean climate streams across different spatial scales. Hydrobiologia 719, 31-42.

Bernhardt, E. S., Band, L. E., Walsh, C. J., and Berke, P. E. (2008). Understanding, managing, and minimizing urban impacts on surface water nitrogen loading. Ann. N.Y. Acad. Sci. 1134, 61-96.

Bernhardt, E. S., Likens, G. E., Hall, R. O., Buso, D. C., Fisher, S. G., Burton, T. M., Meyer, J. L., McDowell, W. H., Mayer, M. S., Bowden, W. B., Findlay, S. E.G., Macneale, K. H., Stelzer, R. S., and Lowe, W. H. (2005). Can't see the forest for the stream? In-stream processing and terrestrial nitrogen exports. BioScience 55 , 219-230.

Bilotta, G. S., Brazier, R. E., and Haygarth, P. M. (2007). The impacts of grazing animals on the quality of soils, vegetation, and surface waters in intensively managed grasslands. Adv. Agron. 94, 237-280.

Blanco, A. C., Nadaoka, K., Yamamoto, T., and Kinjo, K. (2010). Dynamic evolution of nutrient discharge under stormflow and baseflow conditions in a coastal agricultural watershed in Ishigaki Island, Okinawa, Japan. Hydrol. Processes 24, 2601-2616.

Blann, K. L., Anderson, J. L., Sands, G. R., and Vondracek, B. (2009). Effects of agricultural drainage on aquatic ecosystems: A review. Crit. Rev. Environ. Sci. Technol. 39, 909-1001.

Blowes, D. W., Ptacek, C. J., Benner, S. G., McRae, C. W., Bennett, T. A., and Puls, R. W. (2000). Treatment of inorganic contaminants using permeable reactive barriers. J. Contam. Hydrol. 45, 123-137.

Borah, D. K., Bera, M., and Shaw, S. (2003). Water, sediment, nutrient, and pesticide measurements in an agricultural watershed in Illinois during storm events. Am. Soc. Agric. Eng. 46, 657-674. 
Borin, M., Passoni, M., Thiene, M., and Tempesta, T. (2010). Multiple functions of buffer strips in farming areas. Eur.J. Agron. 32, 103-111.

Bosch, D. D., Truman, C. C., Potter, T. L., West, L. T., Strickland, T. C., and Hubbard, R. K. (2012). Tillage and slope position impact on field-scale hydrologic processes in the South Atlantic Coastal Plain. Agric. Water Manage. 111, $40-52$.

Brabec, E., Schulte, S., and Richards, P. L. (2002). Impervious surfaces and water quality: A review of current literature and its implications for watershed planning. J. Plann. Lit. 16, 409-514.

Bremerton CSO Annual Report. (2014). City of Bremerton: Combined sewer overflow annual report 2013, City of Bremerton Press, Bremerton.

$\mathrm{Bu}$, H., Tan, X., Li, S., and Zhang, Q. (2010). Temporal and spatial variations of water quality in the Jinshui River of the South Qinling Mts., China. Ecotoxicol. Environ. Saf. 73, 907-913.

Buda, A. R., and Dewalle, D. R. (2009). Dynamics of stream nitrate sources and flow pathways during stormflows on urban, forest and agricultural watersheds in central Pennsylvania, USA. Hydrol. Processes 23, 3292-3305.

Burgos, P. (2006). Nitrogen mineralization and nitrate leaching of a sandy soil amended with different organic wastes. Waste Manage. Res. 24, 175-182.

Burns, D. A., Boyer, E. W., Elliott, E. M., and Kendall, C. (2009). Sources and transformations of nitrate from streams draining varying land uses: Evidence from dual isotope analysis. J. Environ. Qual. 38, 1149-1159.

Carey, R. O., and Migliaccio, K. W. (2009). Contribution of wastewater treatment plant effluents to nutrient dynamics in aquatic systems: A review. Environ. Manage. 44, 205-217.

Carrico, A. R., Fraser, J., and Bazuin, J. T. (2012). Green with envy: Psychological and social predictors of lawn fertilizer application. Environ. Behav. 20(10), 1-28.

Carrillo, J. H. (2002). Atmospheric deposition of inorganic and organic nitrogen and base cations in Hawaii. Global Biogeochem. Cycles 16, 1076.

Cerdà, A. (2001). Effects of rock fragment cover on soil infilltration, interrill runoff and erosion. Eur. J. Soil Sci. 52, 59-68.

Chang, H. (2008). Spatial analysis of water quality trends in the Han River basin, South Korea. Water Res. 42, 3285-3304.

Chen, D., Huang, H., Hu, M., and Dahlgren, R. A. (2014). Influence of lag effect, soil release, and climate change on watershed anthropogenic nitrogen inputs and riverine export dynamics. Environ. Sci. Technol. 48, 5683-5690.

Chen, D., Lu, J., Shen, Y., Gong, D., and Deng, O. (2011). Spatio-temporal variations of nitrogen in an agricultural watershed in eastern China: Catchment export, stream attenuation and discharge. Environ. Pollut. 159, 2989-2995.

Chen, Y.-H., Wang, M.-K., Wang, G., Chen, M.-H., Luo, D., and Li, R. (2012). Nitrogen runoff under simulated rainfall from a sewage-amended lateritic red soil in Fujian, China. Soil Tillage Res. 123, 35-42.

Collins, R., Mcleod, M., Hedley, M., Donnison, A., Close, M., Hanly, J., Horne, D., and Ross, C. (2007). Best management practices to mitigate faecal contamination by livestock of New Zealand waters. N. Z. J. Agric. Res. 50, 267-278. 
Comly, H.H. (1945). Cyanosis in infants caused by nitrates in well water. J. Am. Med. Assoc., 129, 112.

Cooper, R., Thoss, V., and Watson, H. (2007). Factors influencing the release of dissolved organic carbon and dissolved forms of nitrogen from a small upland headwater during autumn runoff events. Hydrol. Processes 633, 622-633.

Craig, L. S., Palmer, M. A., Richardson, D. C., Filoso, S., Bernhardt, E. S., Bledsoe, B. P., Doyle, M. W., Groffman, P. M., Hassett, B. A., Kaushal, S. S., Mayer, P. M., Smith, S. M., and Wilcock, P. R. (2008). Stream restoration strategies for reducing river nitrogen loads. Front. Ecol. Environ. 6, 529-538.

Daudén, A., Quílez, D., and Vera, M. V. (2004). Pig slurry application and irrigation effects on nitrate leaching in Mediterranean soil lysimeters. J. Environ. Qual. 33, 2290-2295.

Davies-colley, R. O.B.J., Nagels, J. W., Smith, R. O.B.A., Zealand, N., Young, R. G., and Phillips, C. J. (2004). Water quality impact of a dairy cow herd crossing a stream. N. Z. J. Mar. Freshwater Res. 38, 569-576.

De Wit, M., and Bendoricchio, G. (2001). Nutrient fluxes in the Po basin. Sci. Total Environ. 273, 147-161.

Decau, M. L., Simon, J. C., and Jacquet, A. (2004). Nitrate leaching under grassland as affected by mineral nitrogen fertilization and cattle urine. J. Environ. Qual. 33, 637-644.

Di, H. J., and Cameron, K. C. (2000). Calculating nitrogen leaching losses and critical nitrogen application rates in dairy pasture systems using a semi-empirical model. N. Z. J. Agric. Res. 43, 139-147.

Dise, N. B., and Wright, R. F. (1995). Nitrogen leaching from European forests in relation to nitrogen deposition. For. Ecol. Manage. 71, 153-161.

Donohue, I., Styles, D., Coxon, C., and Irvine, K. (2005). Importance of spatial and temporal patterns for assessment of risk of diffuse nutrient emissions to surface waters. J. Hydrol. 304, 183-192.

Drewry, J. J. A. , Newham, L. T. H. A., Greene, R. S. B. B., and Jakeman, A. J.A. (2006). A review of nitrogen and phosphorus export to waterways: Context for catchment modelling. Mar. Freshwater Res. 57, 757-774.

Duffy, J. E., Cardinale, B. J., France, K. E., McIntyre, P. B., Thébault, E., and Loreau, M. (2007). The functional role of biodiversity in ecosystems: Incorporating trophic complexity. Ecol. Lett. 10, 522-538.

Edmonton CSO Control Strategy. (2000). The city of Edmonton: Combined sewer overflow control strategy (Implementation Plan), City of Edmonton Press, Edmonton.

Elliott, A. H., and Carlson, W. T. (2004). Effects of sheep grazing episodes on sediment and nutrient loss in overland flow. Aust. J. Soil Res. 42, 213.

Elmore, A. J., and Kaushal, S. S. (2008). Disappearing headwaters: Patterns of stream burial due to urbanization. Front. Ecol. Environ. 6, 308-312.

European Directive 91/676/CEE. (1991). Retrieved April 17, 2015, from http://ec. europa.eu/environment/water/water-nitrates/directiv.html.

Feng, Z.-Z., Wang, X.-K., and Feng, Z.-W. (2005). Soil N and salinity leaching after the autumn irrigation and its impact on groundwater in Hetao Irrigation District, China. Agric. Water Manage. 71, 131-143. 
Fenton, O., Richards, K. G., Kirwan, L., Khalil, M. I., and Healy, M. G. (2009). Factors affecting nitrate distribution in shallow groundwater under a beef farm in south eastern Ireland. J. Environ. Manage. 90, 3135-3146.

Fewtrell, L. (2004). Drinking-water nitrate, methemoglobinemia, and global burden of disease: A discussion. Environ. Health Perspect. 112, 1371-1374.

Fisher, J., and Acreman, M. C. (2004). Wetland nutrient removal: A review of the evidence. Hydrol. Earth Syst. Sci. 8, 673-685.

Franklin, D., Truman, C., Potter, T., Bosch, D., Strickland, T., and Bednarz, C. (2007). Nitrogen and phosphorus runoff losses from variable and constant intensity rainfall simulations on loamy sand under conventional and strip tillage systems. J. Environ. Qual. 36, 846-854.

Freeman, M. C., Pringle, C. M., and Jackson, C. R. (2007). Hydrologic connectivity and the contribution of stream headwaters to ecological integrity at regional scales. J. Am. Water Resour. Assoc. 43, 5-14.

Gabriel, J. L., Muñoz-Carpena, R., and Quemada, M. (2012). The role of cover crops in irrigated systems: Water balance, nitrate leaching and soil mineral nitrogen accumulation. Agric. Ecosyst. Environ. 155, 50-61.

Galloway, J. N., Townsend, A. R., Erisman, J. W., Bekunda, M., Cai, Z., Freney, J. R., Martinelli, L. A., Seitzinger, S. P., and Sutton, M. A. (2008). Transformation of the nitrogen cycle: Recent trends, questions, and potential solutions. Science 320, 889-892.

Gburek, W. J., Needelman, B. A., and Srinivasan, M. S. (2006). Fragipan controls on runoff generation: Hydropedological implications at landscape and watershed scales. Geoderma 131, 330-344.

Goodridge, B. M., and Melack, J. M. (2012). Land use control of stream nitrate concentrations in mountainous coastal California watersheds. J. Geophys. Res. Biogeosci. 117(G2), G02005.

Goulding, K. W.T., Poulton, P. R., Webster, C. P., and Howe, M. T. (2000). Nitrate leaching from the Broadbalk Wheat Experiment, Rothamsted, UK, as influenced by fertilizer and manure inputs and the weather. Soil Use Manage. 16, 244-250.

Graham, J. L., Stone, M. L., Rasmussen, T. J., and Poulton, B. (2010). Effects of wastewater effluent discharge and treatment facility upgrades on environmental and biological conditions of the Upper Blue River, Johnson County, Kansas and Jackson County, Missouri, January 2003 through March 2009: U.S. Geological Survey Scientific Investigations Report, U.S. Geological Survey Press, Reston.

Greer, F. R., and Shannon, M. (2005). Infant methemoglobinemia: The role of dietary nitrate in food and water. Pediatrics 116, 784-786.

Groffman, P. M., and Crawford, M. K. (2003). Denitrification potential in urban riparian zones. J. Environ. Qual. 32, 1144-1149.

Gu, C., and Riley, W. J. (2010). Combined effects of short term rainfall patterns and soil texture on soil nitrogen cycling-A modeling analysis. J. Contam. Hydrol. 112, 141-154.

Han, H., Allan, J. D., and Scavia, D. (2009). Influence of climate and human activities on the relationship between watershed nitrogen input and river export. Environ. Sci. Technol. 43, 1916-1922. 
Harriman, R., Curtis, C., and Edwards, A. C. (1998). An empirical approach for assessing the relationship between nitrogen deposition and nitrate leaching from upland catchments in the United Kingdom using runoff chemistry. In R. K. Wieder, M. Novák, and J. Černý (Eds.), The third international symposium on ecosystem behavior June 21-25, 1997 (pp. 193-203). Dordrecht: Springer.

Hassanli, A. M., Ebrahimizadeh, M. A., and Beecham, S. (2009). The effects of irrigation methods with effluent and irrigation scheduling on water use efficiency and corn yields in an arid region. Agric. Water Manage. 96, 93-99.

Hättenschwiler, S., Tiunov, A. V., and Scheu, S. (2005). Biodiversity and litter decomposition in terrestrial ecosystems. Annu. Rev. Ecol. Evol. Syst. 36, 191-218.

Holland, E. L.A., Braswell, B. H., and Sulzman, J. (2005). Nitrogen deposition onto the United States and Western Europe: Synthesis of observations and models. Ecol. Appl. 15, 38-57.

Hopp, L., and McDonnell, J. J. (2009). Connectivity at the hillslope scale: Identifying interactions between storm size, bedrock permeability, slope angle and soil depth. J. Hydrol. 376, 378-391.

Hosono, T., Wang, C.-H., Umezawa, Y., Nakano, T., Onodera, S., Nagata, T., Yoshimizu, C., Tayasu, I., and Taniguchi, M. (2011). Multiple isotope (H, O, $\mathrm{N}, \mathrm{S}$ and $\mathrm{Sr}$ ) approach elucidates complex pollution causes in the shallow groundwaters of the Taipei urban area. J. Hydrol. 397, 23-36.

Howarth, R. W. (2008). Coastal nitrogen pollution: A review of sources and trends globally and regionally. Harmful Algae 8, 14-20.

Hubbard, R. K., Newton, G. L., and Hill, G. M. (2004). Water quality and the grazing animal. J. Anim. Sci. 82, E255-E263.

Humborg, C., Mörth, C.M., Sundbom, M. and Wulff, F. (2007). Riverine transport of biogenic elements to the Baltic Sea - past and possible future perspectives. Hydrol. Earth Syst. Sci., 11, 1593-1607.

Hyvönen, R., Agren, G. I., Linder, S., Persson, T., Cotrufo, M. F., Ekblad, A., Freeman, M., Grelle, A., Janssens, I. A., Jarvis, P. G., Kellomäki, S., Lindroth, A., Loustau, D., Lundmark, T., Norby, R. J., Oren, R., Pilegaard, K., Ryan, M. G., Sigurdsson, B. D., Strömgren, M., van Oijen, M., and Wallin, G. (2007). The likely impact of elevated $\left[\mathrm{CO}_{2}\right]$, nitrogen deposition, increased temperature and management on carbon sequestration in temperate and boreal forest ecosystems: A literature review. New Phytol.; 173, 463-480.

Igbinosa, E. O., and Okoh, A. I. (2009). Impact of discharge wastewater effluents on the physico-chemical qualities of a receiving watershed in a typical rural community. Int. J. Environ. Sci. Technol. 6, 175-182.

Jaynes, D. B., Colvin, T. S., Karlen, D. L., Cambardella, C. A., and Meek, D. W. (2001). Nitrate loss in subsurface drainage as affected by nitrogen fertilizer rate. J. Environ. Qual. 30, 1305-1314.

Jiao, J. J., Wang, Y., Cherry, J. A., Wang, X., Zhi, B., Du, H., and Wen, D. (2010). Abnormally high ammonium of natural origin in a coastal aquifer-aquitard system in the Pearl River Delta, China. Environ. Sci. Technol. 44, 7470-7475.

Johnson, L. T., Tank, J. L., Hall Jr., R.O., Mulholland, P. J., Hamilton, S. K., Valett, H. M., Webster, J. R., Bernot, M. J., McDowell, W. H., Peterson, B. J., and Thomas, 
S. M. (2013). Quantifying the production of dissolved organic nitrogen in headwater streams using 15N tracer additions. Limnol. Oceanogr. 4, 1271-1285.

Kaspar, T. C., Jaynes, D. B., Parkin, T. B., and Moorman, T. B. (2007). Rye cover crop and gamagrass strip effects on $\mathrm{NO}_{3}$ concentration and load in tile drainage. $J$. Environ. Qual. 36, 1503-1511.

Kaushal, S. S., Lewis, W. M., and McCutchan, J. H. (2006). Land use change and nitrogen enrichment of a Rocky Mountain watershed. Ecol. Appl. 16, 299-312.

Kaushal, S. S., Groffman, P. M., Band, L. E., Elliott, E. M., Shields, C. A., and Kendall, C. (2011). Tracking nonpoint source nitrogen pollution in human-impacted watersheds. Environ. Sci. Technol. 45, 8225-8232.

Kaushal, S. S., Groffman, P. M., Band, L. E., Shields, C. A., Morgan, R. P., Palmer, M. A., Belt, K. T., Swan, C. M., Findlay, S. E.G., and Fisher, G. T. (2008). Interaction between urbanization and climate variability amplifies watershed nitrate export in Maryland. Environ. Sci. Technol. 42, 5872-5878.

Kim, G., Yur, J., and Kim, J. (2007). Diffuse pollution loading from urban stormwater runoff in Daejeon city, Korea. J. Environ. Manage. 85, 9-16.

Kojima, K., Murakami, M., Yoshimizu, C., Tayasu, I., Nagata, T., and Furumai, H. (2011). Evaluation of surface runoff and road dust as sources of nitrogen using nitrate isotopic composition. Chemosphere 84, 1716-1722.

Kroeger, K. D., Cole, M. L., and Valiela, I. (2006). Groundwater-transported dissolved organic nitrogen exports from coastal watersheds. Limnol. Oceanogr. 51, 2248-2261.

Kurunc, A., Ersahin, S., Uz, B. Y., Sonmez, N. K., Uz, I., Kaman, H., Bacalan, G. E., and Emekli, Y. (2011). Identification of nitrate leaching hot spots in a large area with contrasting soil texture and management. Agric. Water Manage. 98, 1013-1019.

Kurz, I., Coxon, C., Tunney, H., and Ryan, D. (2005). Effects of grassland management practices and environmental conditions on nutrient concentrations in overland flow. J. Hydrol. 304, 35-50.

Lassaletta, L., García-Gómez, H., Gimeno, B. S., and Rovira, J. V. (2009). Agricultureinduced increase in nitrate concentrations in stream waters of a large Mediterranean catchment over 25 years (1981-2005). Sci. Total Environ. 407, 6034-6043.

Laurent, F., and Ruelland, D. (2011). Assessing impacts of alternative land use and agricultural practices on nitrate pollution at the catchment scale. J. Hydrol. 409, 440-450.

Lawrence, G. B., Goolsby, D. A., Battaglin, W. A., and Stensland, G. J. (2000). Atmospheric nitrogen in the Mississippi River Basin-emissions, deposition and transport. Sci. Total Environ. 248, 87-99.

Le Bissonnais, Y., Cerdan, O., Lecomte, V., Benkhadra, H., Souchère, V., and Martin, P. (2005). Variability of soil surface characteristics influencing runoff and interrill erosion. Catena 62, 111-124.

Legout, C., Molenat, J., Aquilina, L., Gascuel-Odoux, C., Faucheux, M., Fauvel, Y., and Bariac, T. (2007). Solute transfer in the unsaturated zone-groundwater continuum of a headwater catchment. J. Hydrol. 332, 427-441.

Li, S., Liu, W., Gu, S., Cheng, X., Xu, Z., and Zhang, Q. (2009). Spatio-temporal dynamics of nutrients in the upper Han River basin, China. J. Hazard. Mater. 162, 1340-1346. 
Li, T., Zhang, W., Feng, C., and Shen, J. (2013). Performance assessment of separate and combined sewer systems in metropolitan areas in southern China. Water Sci. Technol. 69(2), 422-429.

Liang, X.-Q., Xu, L., Li, H., He, M.-M., Qian, Y.-C., Liu, J., Nie, Z.-Y., Ye, Y.-S., and Chen, Y. (2011). Influence of $\mathrm{N}$ fertilization rates, rainfall, and temperature on nitrate leaching from a rainfed winter wheat field in Taihu watershed. Phys. Chem. Earth 36, 395-400.

Liu, X., Duan, L., Mo, J., Du, E., Shen, J., Lu, X., Zhang, Y., Zhou, X., He, C., and Zhang, F. (2011). Nitrogen deposition and its ecological impact in China: An overview. Environ. Pollut. 159, 2251-2264.

Liu, X., Ju, X., Zhang, Y., He, C., Kopsch, J., and Fusuo, Z. (2006). Nitrogen deposition in agroecosystems in the Beijing area. Agric. Ecosyst. Environ. 113, 370-377.

Liu, Y., Tao, Y., Wan, K. Y., Zhang, G. S., Liu, D. B., Xiong, G. Y., and Chen, F. (2012). Runoff and nutrient losses in citrus orchards on sloping land subjected to different surface mulching practices in the Danjiangkou Reservoir area of China. Agric. Water Manage. 110, 34-40.

Liu, Z., Yang, J., Yang, Z., and Zou, J. (2012). Effects of rainfall and fertilizer types on nitrogen and phosphorus concentrations in surface runoff from subtropical tea fields in Zhejiang, China. Nutr. Cycling Agroecosyst. 93, 297-307.

Luo, Y., Yang, X., Carley, R. J., and Perkins, C. (2003). Effects of geographical location and land use on atmospheric deposition of nitrogen in the State of Connecticut. Environ. Pollut. 124, 437-448.

Mangimbulude, J. C., van Breukelen, B. M., Krave, A. S., van Straalen, N. M., and Röling, W. F.M. (2009). Seasonal dynamics in leachate hydrochemistry and natural attenuation in surface run-off water from a tropical landfill. Waste Manage. 29, 829-838.

Mantovi, P., Fumagalli, L., Beretta, G. P., and Guermandi, M. (2006). Nitrate leaching through the unsaturated zone following pig slurry applications. J. Hydrol. 316, $195-212$.

Marques, M. (2007). Stormwater runoff pollution at waste management sites. Urban Water J. 4, 173-181.

Masetti, M., Poli, S., Sterlacchini, S., Beretta, G. P., and Facchi, A. (2008). Spatial and statistical assessment of factors influencing nitrate contamination in groundwater. J. Environ. Manage. 86, 272-281.

McClain, M. E., Boyer, E. W., Dent, C. L., Gergel, S. E., Grimm, N. B., Groffman, P. M., Hart, S. C., Harvey, J. W., Johnston, C. A., Mayorga, E., McDowell, W. H., and Pinay, G. (2003). Biogeochemical hot spots and hot moments at the interface of terrestrial and aquatic ecosystems. Ecosystems 6, 301-312.

McDaniel, P. A., Regan, M. P., Brooks, E., Boll, J., Barndt, S., Falen, A., Young, S. K., and Hammel, J. E. (2008). Linking fragipans, perched water tables, and catchment-scale hydrological processes. Catena 73, 166-173.

McGechan, M., and Topp, C. F. (2004). Modelling environmental impacts of deposition of excreted nitrogen by grazing dairy cows. Agric. Ecosyst. Environ. 103, 149-164. 
Merseburger, G., Martí, E., and Sabater, F. (2005). Net changes in nutrient concentrations below a point source input in two streams draining catchments with contrasting land uses. Sci. Total Environ. 347, 217-229.

Merseburger, G., Martí, E., Sabater, F., and Ortiz, J. D. (2011). Point-source effects on $\mathrm{N}$ and $\mathrm{P}$ uptake in a forested and an agricultural Mediterranean streams. Sci. Total Environ. 409, 957-967.

Meyles, E., Williams, A., Ternan, L., and Dowd, J. (2003). Runoff generation in relation to soil moisture patterns in a small Dartmoor catchment, Southwest England. Hydrol. Processes 17, 251-264.

Mian, I. A., Riaz, M., and Cresser, M. S. (2009). The importance of ammonium mobility in nitrogen-impacted unfertilized grasslands: A critical reassessment. Environ. Pollut. 157, 1287-1293.

Molenat, J., Gascuel-Odoux, C., Ruiz, L., and Gruau, G. (2008). Role of water table dynamics on stream nitrate export and concentration in agricultural headwater catchment (France). J. Hydrol. 348, 363-378.

Morton, T. G., Gold, A. J., and Sullivan, W. M. (1988). Influence of overwatering and fertilization on nitrogen losses from home lawns. J. Environ. Qual. 17, 124.

Mousavi, S., Ibrahim, S., Aroua, M. K., and Ghafari, S. (2012). Development of nitrate elimination by autohydrogenotrophic bacteria in bio-electrochemical reactors-A review. Biochem. Eng. J. 67, 251-264.

Mulholland, P. J., Helton, A. M., Poole, G. C., Hall, R. O., Hamilton, S. K., Peterson, B. J., Tank, J. L., Ashkenas, L. R., Cooper, L. W., Dahm, C. N., Dodds, W. K., Findlay, S. E.G., Gregory, S. V., Grimm, N. B., Johnson, S. L., McDowell, W. H., Meyer, J. L., Valett, H. M., Webster, J. R., Arango, C. P., Beaulieu, J. J., Bernot, M. J., Burgin, A. J., Crenshaw, C. L., Johnson, L. T., Niederlehner, B. R., O’Brien, J. M., Potter, J. D., Sheibley, R. W., Sobota, D. J., and Thomas, S. M. (2008). Stream denitrification across biomes and its response to anthropogenic nitrate loading. Nature 452, 202-205.

Needelman, B. A., Gburek, W. J., Petersen, G. W., Sharpley, A. N., and Kleinman, P. J.A. (2004). Surface runoff along two agricultural hillslopes with contrasting soils. Soil Sci. Soc. Am. J. 68, 914-923.

Norton, M., and Fisher, T. (2000). The effects of forest on stream water quality in two coastal plain watersheds of the Chesapeake Bay. Ecol. Eng. 14, 337-362.

Nyenje, P. M., Foppen, J. W., Uhlenbrook, S., Kulabako, R., and Muwanga, A. (2010). Eutrophication and nutrient release in urban areas of sub-Saharan Africa: A review. Sci. Total Environ. 408, 447-455.

Ohte, N. (2012). Implications of seasonal variation in nitrate export from forested ecosystems: A review from the hydrological perspective of ecosystem dynamics. Ecol. Res. 27, 657-665.

Ojeda, G., Tarrasón, D., Ortiz, O., and Alcañiz, J. M. (2006). Nitrogen losses in runoff waters from a loamy soil treated with sewage sludge. Agric. Ecosyst. Environ. 117, 49-56.

Oman, C. B., and Junestedt, C. (2008). Chemical characterization of landfill leachates-400 parameters and compounds. Waste Manage. 28, 1876-1891.

Paerl, H. W., Dennis, R. L., and Whitall, D. R. (2002). Atmospheric deposition of nitrogen: Implications for nutrient over-enrichment of coastal waters. Estuaries 25, 677-693. 
Pärn, J., Pinay, G., and Mander, Ü. (2012). Indicators of nutrients transport from agricultural catchments under temperate climate: A review. Ecol. Indic. 22, 4-15.

Patil, R. H., Laegdsmand, M., Olesen, J. E., and Porter, J. R. (2010). Effect of soil warming and rainfall patterns on soil N cycling in Northern Europe. Agric. Ecosyst. Environ. 139, 195-205.

Paul, M. J., and Meyer, J. L. (2001). Streams in the urban landscape. Urban Ecol. 32, $333-365$.

Pellerin, B. A., Kaushal, S. S., and McDowell, W. H. (2006). Does anthropogenic nitrogen enrichment increase organic nitrogen concentrations in runoff from forested and human-dominated watersheds? Ecosystems 9, 852-864.

Penna, D., Meerveld, H. J., Gobbi, A., Borga, M., and Dalla Fontana, G. (2011). The influence of soil moisture on threshold runoff generation processes in an alpine headwater catchment. Hydrol. Earth Syst. Sci. 15, 689-702.

Peterson, B. J., Wollheim, W. M., Mulholland, P. J., Webster, J. R., Meyer, J. L., Tank, J. L., Marti, E., Bowden, W. B., Valett, H. M., Hershey, A. E., McDowell, W. H., Dodds, W. K., Hamilton, S. K., Gregory, S., and Morrall, D. D. (2001). Control of nitrogen export from watersheds by headwater streams. Science 292, 86-90.

Petrovic, A. M. (1990). The fate of nitrogenous fertilizers applied to turfgrass. $J$. Environ. Qual. 19(1), 1-14.

Phan, L. T., Bui, T. M., Nguyen, T. T.T., Gooley, G. J., Ingram, B. A., Nguyen, H. V., Nguyen, P. T., and De Silva, S. S. (2009). Current status of farming practices of striped catfish, Pangasianodon hypophthalmus in the Mekong Delta, Vietnam. Aquaculture 296, 227-236.

Puigdefábregas, J. (2005). The role of vegetation patterns in structuring runoff and sediment fluxes in drylands. Earth Surf. Processes Landforms 30, 133-147.

Ramos, M. C., and Martínez-Casasnovas, J. A. (2006). Nutrient losses by runoff in vineyards of the Mediterranean Alt Penedès region (NE Spain). Agric. Ecosyst. Environ. 113, 356-363.

Ranalli, A. J., and Macalady, D. L. (2010). The importance of the riparian zone and in-stream processes in nitrate attenuation in undisturbed and agricultural watersheds-A review of the scientific literature. J. Hydrol. 389, 406-415.

Rao, N. S., Easton, Z. M., Schneiderman, E. M., Zion, M. S., Lee, D. R., and Steenhuis, T. S. (2009). Modeling watershed-scale effectiveness of agricultural best management practices to reduce phosphorus loading. J. Environ. Manage. 90, $1385-1395$.

Reay, W. G. (2004). Septic tank impacts on ground water quality and nearshore sediment nutrient flux. Ground Water 42, 1079-1089.

Renou, S., Givaudan, J. G., Poulain, S., Dirassouyan, F., and Moulin, P. (2008). Landfill leachate treatment: Review and opportunity. J. Hazard. Mater. 150, 468-493.

Rimski-Korsakov, H., Rubio, G., and Lavado, R. S. (2004). Potential nitrate losses under different agricultural practices in the pampas region, Argentina. Agric. Water Manage. 65, 83-94.

Robertson, G. P., and Groffman, P. (2007). Nitrogen transformations. Soil Microbiol. Biochem. Ecol. 341-364.

Rouxel, M., Molénat, J., Ruiz, L., Legout, C., Faucheux, M., and Gascuel-Odoux, C. (2011). Seasonal and spatial variation in groundwater quality along the hillslope 
of an agricultural research catchment (Western France). Hydrol. Processes 25, 831-841.

Royer, T. V., David, M. B., and Gentry, L. E. (2006). Timing of riverine export of nitrate and phosphorus from agricultural watersheds in Illinois: Implications for reducing nutrient loading to the Mississippi River. Environ. Sci. Technol. 40, 4126-4131.

Royer, T. V., Tank, J. L., and David, M. B. (2004). Landscape and watershed processes transport and fate of nitrate in headwater agricultural streams in Illinois. $J$. Environ. Qual. 33, 1296-1304.

Ruiz, L., Abiven, S., Durand, P., Martin, C., Vertès, F., and Beaujouan, V. (2002a). Effect on nitrate concentration in stream water of agricultural practices in small catchments in Brittany: I. Annual nitrogen budgets. Hydrol. Earth Syst. Sci. 6, 497-506.

Ruiz, L., Abiven, S., Martin, C., Durand, P., Beaujouan, V., and Molénat, J. (2002b). Effect on nitrate concentration in stream water of agricultural practices in small catchments in Brittany: II. Temporal variations and mixing processes. Hydrol. Earth Syst. Sci. 6, 507-514.

Ryther, J. H., and Dunstan, W. M. (1971). Nitrogen, phosphorus, and eutrophication in the coastal marine environment. Science 171, 1008-1013.

Sahu, M., and Gu, R. R. (2009). Modeling the effects of riparian buffer zone and contour strips on stream water quality. Ecol. Eng. 35, 1167-1177.

Schilling, K., and Zhang, Y.-K. (2004). Baseflow contribution to nitrate-nitrogen export from a large, agricultural watershed, USA. J. Hydrol. 295, 305-316.

Schindler, D. W., Dillon, P. J., and Schreier, H. (2006). A review of anthropogenic sources of nitrogen and their effects on Canadian aquatic ecosystems. Biogeochemistry 79, 25-44.

Schmidt, C. A., and Clark, M. W. (2012). Efficacy of a denitrification wall to treat continuously high nitrate loads. Ecol. Eng. 42, 203-211.

Schulz, M., Kozerski, H.-P., Pluntke, T., and Rinke, K. (2003). The influence of macrophytes on sedimentation and nutrient retention in the lower River Spree (Germany). Water Res. 37, 569-578.

Sebestyen, S. D., Boyer, E. W., Shanley, J. B., Kendall, C., Doctor, D. H., Aiken, G. R., and Ohte, N. (2008). Sources, transformations, and hydrological processes that control stream nitrate and dissolved organic matter concentrations during snowmelt in an upland forest. Water Resour. Res. 44, W12410.

Seitzinger, S., Harrison, J. A., Böhlke, J. K., Bouwman, A. F., Lowrance, R., Peterson, B., Tobias, C., and Van Drecht, G. (2006). Denitrification across landscapes and waterscapes: A synthesis. Ecol. Appl. 16, 2064-2090.

Sheriff, G. (2005). Efficient waste? Why farmers over-apply nutrients and the implications for policy design. Rev. Agric. Econ. 27, 542-557.

Shields, C. A., Band, L. E., Law, N., Groffman, P. M., Kaushal, S. S., Savvas, K., Fisher, G. T., and Belt, K. T. (2008). Streamflow distribution of non-point source nitrogen export from urban-rural catchments in the Chesapeake Bay watershed. Water Resour. Res. 44, 1-13.

Shrestha, S., and Kazama, F. (2007). Assessment of surface water quality using multivariate statistical techniques: A case study of the Fuji river basin, Japan. Environ. Modell. Software 22, 464-475. 
Sindilariu, P.-D., Reiter, R., and Wedekind, H. (2009). Impact of trout aquaculture on water quality and farm effluent treatment options. Aquat. Living Resour. 22, 93-103.

Smith, R. G., Gross, K. L., and Robertson, G. P. (2008). Effects of crop diversity on agroecosystem function: Crop yield response. Ecosystems 11, 355-366.

Soonthornnonda, P., and Christensen, E. R. (2008). Source apportionment of pollutants and flows of combined sewer wastewater. Water Res. 42, 1989-1998.

Sutton, M. A., Howard, C. M., Erisman, J. W., Billen, G., Bleeker, A., Grennfelt, P., van Grinsven, H., and Grizzetti, B. (2011). The European nitrogen assessment: Sources, effects and policy perspectives. Cambridge University Press: Cambridge.

Tang, J.-L., Zhang, B., Gao, C., and Zepp, H. (2008). Hydrological pathway and source area of nutrient losses identified by a multi-scale monitoring in an agricultural catchment. Catena 72, 374-385.

Tanner, C. C., Sukias, J. P.S., Headley, T. R., Yates, C. R., and Stott, R. (2012). Constructed wetlands and denitrifying bioreactors for on-site and decentralised wastewater treatment: Comparison of five alternative configurations. Ecol. Eng. 42, 112-123.

Taylor, G. D., Fletcher, T. D., Wong, T. H.F., Breen, P. F., and Duncan, H. P. (2005). Nitrogen composition in urban runoff-Implications for stormwater management Water Res., 39, 1982-1989.

Thieu, V., Garnier, J., and Billen, G. (2010). Assessing the effect of nutrient mitigation measures in the watersheds of the Southern Bight of the North Sea. Sci. Total Environ. 408, 1245-1255.

Thomas, O., Jung, A. V., Causse, J., Louyer, M. V., Piel, S., Baurès, E., and Thomas, M. F. (2014). Revealing organic carbon-nitrate linear relationship from UV spectra of freshwaters in agricultural environment. Chemosphere 107, $115-120$.

Thompson, R. B., Martínez-Gaitan, C., Gallardo, M., Giménez, C., and Fernández, M. D. (2007). Identification of irrigation and $\mathrm{N}$ management practices that contribute to nitrate leaching loss from an intensive vegetable production system by use of a comprehensive survey. Agric. Water Manage. 89, 261-274.

Tian, S., Youssef, M. A., Skaggs, R. W., Amatya, D. M., and Chescheir, G. M. (2012). Temporal variations and controlling factors of nitrogen export from an artificially drained coastal forest. Environ. Sci. Technol. 46, 9956-9963.

Tomer, M. D., Meek, D. W., Jaynes, D. B., and Hatfield, J. L. (2003). Evaluation of nitrate nitrogen fluxes from a tile-drained watershed in Central Iowa. J. Environ. Qual. 32, 642-653.

Tromp-van Meerveld, H. J., and McDonnell, J. J. (2006). Threshold relations in subsurface stormflow: 1. A 147-storm analysis of the Panola hillslope. Water Resour. Res. 42, W02410.

Tromp-van Meerveld, H. J., Peters, N. E., and Mcdonnell, J. J. (2007). Effect of bedrock permeability on subsurface stormflow and the water balance of a trenched hillslope at the Panola Mountain Research Watershed, Georgia, USA. Hydrol. Processes 769, 750-769. 
Truman, C. C., Potter, T. L., Nuti, R. C., Franklin, D. H., and Bosch, D. D. (2011). Antecedent water content effects on runoff and sediment yields from two Coastal Plain Ultisols. Agric. Water Manage. 98, 1189-1196.

Uchida, T., Meerveld, H. J., and McDonnell, J. J. (2005). The role of lateral pipe flow in hillslope runoff response: An intercomparison of non-linear hillslope response. J. Hydrol. 311, 117-133.

Udawatta, R.P., Motavalli, P.P., Garrett, H.E. and Krstansky, J.J., (2006). Nitrogen losses in runoff from three adjacent agricultural watersheds with claypan soils, Agric. Ecosyst. Environ., 117, 39-48.

Umezawa, Y., Hosono, T., Onodera, S., Siringan, F., Buapeng, S., Delinom, R., Yoshimizu, C., Tayasu, I., Nagata, T., and Taniguchi, M. (2009). Erratum to "Sources of nitrate and ammonium contamination in groundwater under developing Asian megacities". Sci. Total Environ. 407(9), 3219-3231.

USEPA. (2004). Report to Congress on the Impacts and Control of CSOs and SSOs. Chapter 5 - Environmental Impacts of CSOs and SSOs. US. EPA Press, Washington.

USEPA. (2009). Combined sewer overflow controls in Southeast Michigan. Retrieved April 17, 2015, from http://www.epa.gov/med/grosseile_site/indicators/cso. html.

Vázquez, N., Pardo, A., Suso, M. L., and Quemada, M. (2006). Drainage and nitrate leaching under processing tomato growth with drip irrigation and plastic mulching. Agric. Ecosyst. Environ. 112, 313-323.

Vidon, P., Allan, C., Burns, D., Duval, T. P., Gurwick, N., Inamdar, S., Lowrance, R., Okay, J., Scott, D., Sebestyen, S., and Low, R. (2010). Hot spots and hot moments in riparian zones: potential for improved water quality management. J. Am. Water Resour. Assoc. 46(2), 278-298.

Vymazal, J. (2007). Removal of nutrients in various types of constructed wetlands. Sci. Total Environ. 380, 48-65.

Wagenschein, D., and Rode, M. (2008). Modelling the impact of river morphology on nitrogen retention-A case study of the Weisse Elster River (Germany). Ecol. Modell. 211, 224-232.

Wakida, F. T., and Lerner, D. N. (2005). Non-agricultural sources of groundwater nitrate: A review and case study. Water Res. 39, 3-16.

Wakida, F. T., and Lerner, D. N. (2006). Potential nitrate leaching to groundwater from house building. Hydrol. Processes 20, 2077-2081.

Ward, M. H., deKok, T. M., Levallois, P., Brender, J., Gulis, G., Nolan, B. T., and VanDerslice, J. (2005). Workgroup report: Drinking-water nitrate and health-recent findings and research needs. Environ. Health Perspect. 113, 1607-1614.

Wei, L., Zhang, B., and Wang, M. (2007). Effects of antecedent soil moisture on runoff and soil erosion in alley cropping systems. Agric. Water Manage. 94, 54-62.

Wei, Y., Davidson, B., Chen, D., and White, R. (2009). Balancing the economic, social and environmental dimensions of agro-ecosystems: An integrated modeling approach. Agric. Ecosyst. Environ. 131, 263-273.

Withers, P. J.A., and Jarvie, H. P. (2008). Delivery and cycling of phosphorus in rivers: A review. Sci. Total Environ. 400, 379-395. 
Wohlfart, T., Exbrayat, J.-F., Schelde, K., Christen, B., Dalgaard, T., Frede, H.-G., and Breuer, L. (2012). Spatial distribution of soils determines export of nitrogen and dissolved organic carbon from an intensively managed agricultural landscape. Biogeosciences 9, 4513-4525.

Wollheim, W. M., Pellerin, B. A., Vörösmarty, C. J., and Hopkinson, C. S. (2005). N retention in urbanizing headwater catchments. Ecosystems 8, 871-884.

Wu, L., Long, T., Liu, X., and Guo, J. (2012). Impacts of climate and land-use changes on the migration of non-point source nitrogen and phosphorus during rainfallrunoff in the Jialing River Watershed, China. J. Hydrol. 475, 26-41.

Zhang, Q., Streets, D. G., Carmichael, G. R., He, K. B., Huo, H., Kannari, A., Klimont, Z., Park, I. S., and Reddy, S. (2009). Asian emissions in 2006 for the NASA INTEX-B mission. Atmos. Chem. Phys. 9, 5131-5153.

Zheng, F.-L., Huang, C.-H., and Norton, L. D. (2004). Effects of near-surface hydraulic gradients on nitrate and phosphorus losses in surface runoff. J. Environ. Qual. 33, 2174-2182.

Zhou, J.-B., Xi, J.-G., Chen, Z.-J., and Li, S.-X. (2006). Leaching and transformation of nitrogen fertilizers in soil after application of $\mathrm{N}$ with irrigation: A soil column method. Pedosphere 16, 245-252. 